NBER WORKING PAPER SERIES

\title{
REFUGEES FROM DUST AND SHRINKING LAND: TRACKING THE DUST BOWL MIGRANTS
}

\author{
Jason Long \\ Henry E. Siu \\ Working Paper 22108 \\ http://www.nber.org/papers/w22108 \\ NATIONAL BUREAU OF ECONOMIC RESEARCH \\ 1050 Massachusetts Avenue \\ Cambridge, MA 02138 \\ March 2016
}

We thank Price Fishback, Josh Gottlieb, Rick Hornbeck, Lawrence Katz, Marianne Wanamaker, Nick Ziebarth, and workshop participants at Iowa, UBC, and the NBER Summer Institute for helpful comments. Madeleine Armour, Aliya Dossa, Beth Fowler, Liane Hewitt, Sophia Jit, Tim Lazar, Harry Mak, Josiah Sledge, Jasmine Tan, Travis Tos, and, especially, Alix Duhaime-Ross and Dennis Wang provided exceptional research assistance. Long thanks the National Science Foundation and Siu thanks the Social Sciences and Humanities Research Council of Canada for support. The first part of our title comes from Chapter 12 of John Steinbeck's novel, The Grapes of Wrath. The views expressed herein are those of the authors and do not necessarily reflect the views of the National Bureau of Economic Research.

NBER working papers are circulated for discussion and comment purposes. They have not been peer-reviewed or been subject to the review by the NBER Board of Directors that accompanies official NBER publications.

(C) 2016 by Jason Long and Henry E. Siu. All rights reserved. Short sections of text, not to exceed two paragraphs, may be quoted without explicit permission provided that full credit, including () notice, is given to the source. 
Refugees From Dust and Shrinking Land: Tracking the Dust Bowl Migrants

Jason Long and Henry E. Siu

NBER Working Paper No. 22108

March 2016

JEL No. J61,J62,N12,N32

\begin{abstract}
$\underline{\text { ABSTRACT }}$
We construct longitudinal data from the U.S. Census records to study migration patterns of those affected by the Dust Bowl of the 1930s. Our focus is on the famous "Okie" migration of the Southern Great Plains. We find that migration rates were much higher in the Dust Bowl than elsewhere in the U.S. This difference is due to the fact that individuals who were typically unlikely to move (e.g., those with young children, those living in their birth state) were equally likely to move in the Dust Bowl. While this result of elevated mobility conforms to long-standing perceptions of the Dust Bowl, our other principal findings contradict conventional wisdom. First, relative to other occupations, farmers in the Dust Bowl were the least likely to move; this relationship between mobility and occupation was unique to that region. Second, out-migration rates from the Dust Bowl region were only slightly higher than they were in the 1920s. Hence, the depopulation of the Dust Bowl was due largely to a sharp drop in migration inflows. Dust Bowl migrants were no more likely to move to California than migrants from other parts of the U.S., or those from the same region ten years prior. In this sense, the westward push from the Dust Bowl to California was unexceptional. Finally, migration from the Dust Bowl was not associated with long-lasting negative labor market effects, and for farmers, the effects were positive.
\end{abstract}

\author{
Jason Long \\ Department of Business \& Economics \\ Wheaton College \\ 501 College Ave \\ Wheaton, IL 60187 \\ jason.long@wheaton.edu \\ Henry E. Siu \\ Vancouver School of Economics \\ University of British Columbia \\ 6000 Iona Drive \\ Vancouver, BC V6T 1L4 \\ Canada \\ and NBER \\ hankman@mail.ubc.ca
}




\section{Introduction}

The Dust Bowl of the 1930s was one of the greatest environmental and economic catastrophes in U.S. history. The severity of its environmental degradation, farm failure, and economic dislocation have cemented the episode's place in the mythology of the American experience. Perhaps the most enduring image of the Dust Bowl is the exodus of destitute farmers and other "Okies" from the Southern Great Plains, one of the most famous episodes of internal migration in American history. However, little systematic evidence has been brought to bear on even the basic contours of this migration episode. This research represents the first attempt to quantify and analyze gross migration flows associated with this event.

The Dust Bowl occurred as the confluence of drought, erosion, and economic depression throughout the Great Plains. The drought began in the winter of 1931; throughout most of the 1930s, and especially mid-decade, minimal precipitation, high winds, and pestilence led to widespread crop failure. While the effects were widespread, matters were most severe in the Southern Plains states of Colorado, Kansas, Oklahoma, and Texas (see Joel (1937), Cunfer (2011)), and the out-migration from this region looms largest in the formation of the Dust Bowl narrative.

Poor seasons were not new to the Plains in the 1930s. Yet in many ways the decade was unprecedented. One fundamental difference from previous droughts was the number of people affected. Between 1890 and 1930, the population of the Southern Plains states had increased from $4,496,000$ to $11,561,000$. In the counties most greatly affected by the Dust Bowl (as defined below), the population had increased from 14,000 to 121,000. Most striking was the severity of the drought, the worst in over a hundred years of formal meteorological record keeping. ${ }^{1}$ Dust storms, like the famous Black Sunday storm of April 1935, were also more frequent and damaging. Severe wind erosion and occasional water erosion resulted in widespread loss of topsoil and declining agricultural productivity. These problems were exacerbated by the externalities associated with small-scale Plains agriculture, which dis-incentivized farmers from engaging in basic erosion prevention measures (see Hansen and Libecap (2004)).

The environmental calamity coincided with the U.S. and international Great Depression. Together, these shocks amplified long term structural change in agriculture, due to mechanization and consolidation, and falling agricultural prices since the end of the First World War. Prices fell precipitously in the early 1930s, severely impacting farm incomes. Wheat prices fell from $\$ 1.18$ per bushel in 1928 to 38 cents per bushel in 1932 and 1933; cotton prices fell from 19 cents to 6 cents per pound during the same period. ${ }^{2}$ Falling incomes, coupled with farmers' declining access to credit due to the financial sector crisis, led to foreclosure and farm loss.

\footnotetext{
${ }^{1}$ For more on this and on the general history of the Dust Bowl, see Worster (1979) and Cunfer (2005).

${ }^{2}$ See U.S. Department of Agriculture's Economic Research Service, http://www.ers.usda.gov/, and U.S. Bureau of Agricultural Economics (1939).
} 
As a result, the region experienced marked depopulation. During the Dust Bowl decade, the most greatly affected counties shrank by 20 percent. More broadly, Hornbeck (2012) shows that population declined by 12 percent in those Great Plains counties that experienced the highest levels of erosion relative to counties with less erosion. This trend was long-lasting as the bulk of long-run reallocation of productive factors away from agriculture was achieved through population decline as opposed to adjustments in land use.

This displacement led to much public hand-wringing and anger in places receiving the "tide of migration...sweeping over the country" (see U.S. House (1941), page 68), and gave rise to derogatory terms such as Okies and "Dust Bowl refugees." Perhaps the most vivid example is that of the Los Angeles Police sending officers to patrol the California borders in order to stem the immigration (see Los Angeles Herald-Express, Feb 4, 1936). No doubt, the "transient problem" was more general in scope, due to the joblessness created by the Great Depression. But in the 74th Congress' Senate Resolution 298 to investigate "the social and economic needs of laborers migrating across state lines," and the establishment of the select committee by the 76th Congress to "investigate the interstate migration of destitute citizens," it is clear that one of the primary concerns was the issue of those fleeing the Dust Bowl. (see, for instance, the Introductory Statement to U.S. House (1941).)

These factors came together to cement the Dust Bowl's place in American myth, and to make the exodus from the Southern Great Plains one of the most famous episodes of internal migration in U.S. history. The Dust Bowl loomed large in literature, art, and music - from the iconic images of the Farm Security Administration photography corps documenting the plight of Plains farmers and its migrants, to the folk songs of Woody Guthrie, to films like Pare Lorentz's The Plow that Broke the Plains. Certainly the most enduring depiction in this regard remains John Steinbeck's The Grapes of Wrath, whose portrayal of the Joad family's move to California has done so much to shape popular perception of Dust Bowl migration. Finally, the high-profile New Deal agencies and programs aimed at ameliorating the agricultural problems of the Dust Bowl drew attention to the region and its difficulties.

While much attention has been paid to the Dust Bowl and its depopulation, much remains unknown with respect to the relevant migration dynamics and the migrants themselves. To date, we lack systematic, representative data on individuals residing in the relevant Southern Great Plains counties before the Dust Bowl occurred, their characteristics, and how their lives were affected after the crisis abated. ${ }^{3}$ This research represents the first attempt to measure gross migration associated with this event by assembling and analyzing just such data. We document

\footnotetext{
${ }^{3}$ See, for instance, Ferrie (2003) who discusses the lack of migration data prior to the 1940 census. Prior to this study, nationally representative data on gross migration has been available from the Census Bureau only for the period 1935-1940. Analysis of that data has also been at a much coarser (state and/or census division) level than that considered here, and includes little information on the characteristics of migrants; see U.S. Bureau of the Census (1946).
} 
migration among the Okies of the Southern Plains - those at the heart of the exodus mythology. We document where residents of these counties in 1930 moved to and resided in 1940. We also discuss how migration probabilities covaried by individual- and county-level characteristics. Finally, we study the economic effects of migration from the Dust Bowl.

In order to study migration phenomena, we construct new longitudinal data at the individual level for the decade between 1930 and 1940, and for the decade between 1920 and 1930. We do this by linking individuals across U.S. Decennial Censuses.

We find that inter-county and inter-state migration rates were much higher in the Dust Bowl counties than elsewhere in the U.S. during the 1930s. This difference is due to the fact that individual-level characteristics that were negatively associated with mobility elsewhere (e.g., being married, having young children, living in one's birth state), were unrelated to migration probability within the Dust Bowl. While this result conforms to long-standing perceptions of the Dust Bowl, our other principal findings contradict conventional wisdom. First, relative to other occupational groups, farmers in the Dust Bowl were the least likely to move; by contrast, no such relationship existed between migration probability and occupation outside of the Dust Bowl. Second, while the out-migration rate from the Dust Bowl was high (relative to other parts of the country), it was not much higher than from the same region in the 1920s. Hence, the depopulation of the Dust Bowl was due principally to a sharp drop in in-migration during the 1930s. Migrants from the Dust Bowl were no more likely to move to California than migrants from any other part of the country. Instead, Dust Bowl migrants made relatively "local" moves, tending to remain in a Dust Bowl-affected state. Finally, we find that migrants from the Dust Bowl did not experience long-lasting negative labor market outcomes relative to those who stayed; for farmers, migration effects were positive. These findings hold both in terms of reducedform correlation, and within the context of a structural model accounting for migrant selection.

\section{Methodology and Data}

We use two sources to construct our longitudinal data: a computerized five percent sample of the 1930 census, made available by IPUMS (see Ruggles et al. (2010)), and the complete count 1920, 1930 and 1940 censuses, accessible through Ancestry.com, a web-based genealogical research service.

With these sources we construct three datasets: (i) 4,210 individuals living in a "Dust Bowl county" (as defined below) in 1930, linked to the 1940 census, (ii) 2,090 individuals living in those same counties in 1920, linked to the 1930 census, and (iii) a nationally-representative sample of 4,335 individuals linked between the 1930 and 1940 censuses. All of our linked individuals are male household heads (simply referred to as heads hereafter), between 16 and 60 years of age in the relevant source year census. Our definition of a head includes individuals designated as the 
"head of the family" by census enumerators, as well as non-family males (e.g., boarders, lodgers, hired men) residing in group quarters or in homes where a family head is present.

Individuals were linked based on given name(s), last name, race, state of birth, and year of birth-information that should, barring error, remain constant across censuses. The linkages were constructed manually by trained researchers. Automated linkage was unsuitable for this project for two reasons. First, a digitized version of the 1940 census was not available when the research project was begun. Second, constructing the datasets for the Dust Bowl counties required many more men living in those counties in the source years of 1920 and 1930 than are available from the IPUMS census samples. For these counties, it was necessary to draw both the pool of target individuals from the source year census and their linked record from the terminal year census from Ancestry.com.

Some leeway in the matching algorithm was allowed for small discrepancies in reporting personal information across census surveys. Given names were allowed to vary slightly as long as they matched phonetically and last names matched identically; last names were allowed to vary by one letter as long as they matched phonetically and given name(s) matched. Reported age in the terminal year census was allowed to deviate by up to three years from the value reported in the source year. ${ }^{4}$

This linkage procedure produced datasets that are well representative of the target populations. Table 11 in Appendix A provides a summary of the data constructed and analyzed in the rest of this paper. Table 12 in Appendix A presents the same summary statistics for a random sample of heads drawn from IPUMS, indicating the representativeness of our matched sample.

Though varying degrees of drought and erosion were experienced throughout the Plains states (see, for instance, Hansen and Libecap (2004) and Hornbeck (2012)), we chose to focus our attention on the Dust Bowl of the Southern Great Plains for two reasons. First, this is the region at the heart of the exodus mythology as typified by the famous Okie migrants. Second, it is consistent with the U.S. Department of Agriculture's Soil Conservation Service (SCS) contemporaneous definition of the areas most severely affected by the Dust Bowl. Beginning in August of 1934, the Soil Erosion Service (which became the SCS in 1935) began an extensive survey of soil type, land use, wind erosion, and soil accumulation throughout every state in the U.S. (see Cunfer (2011) for details). By 1936, the SCS had identified the single worst wind-eroded area in the country: a cluster of contiguous counties centered around the Oklahoma and Texas panhandles. This covered sixteen million acres of land, and comprised the twenty counties of: Baca, Bent, and Prowers in Colorado; Grant, Hamilton, Morton, Seward, Stanton, and Stevens

\footnotetext{
${ }^{4}$ Complete details of the data construction process, including specific training protocols for manual linkage, are available from the authors upon request. Similar procedures have been used to construct longitudinal data from various national censuses. See, for instance, Long (2005), Abramitzky et al. (2012), and Long and Ferrie (2013). See Ferrie (2003) for a general discussion on the use of linked census data, and other data sources, in the study of internal migration.
} 
Figure 1: Dust Bowl Counties

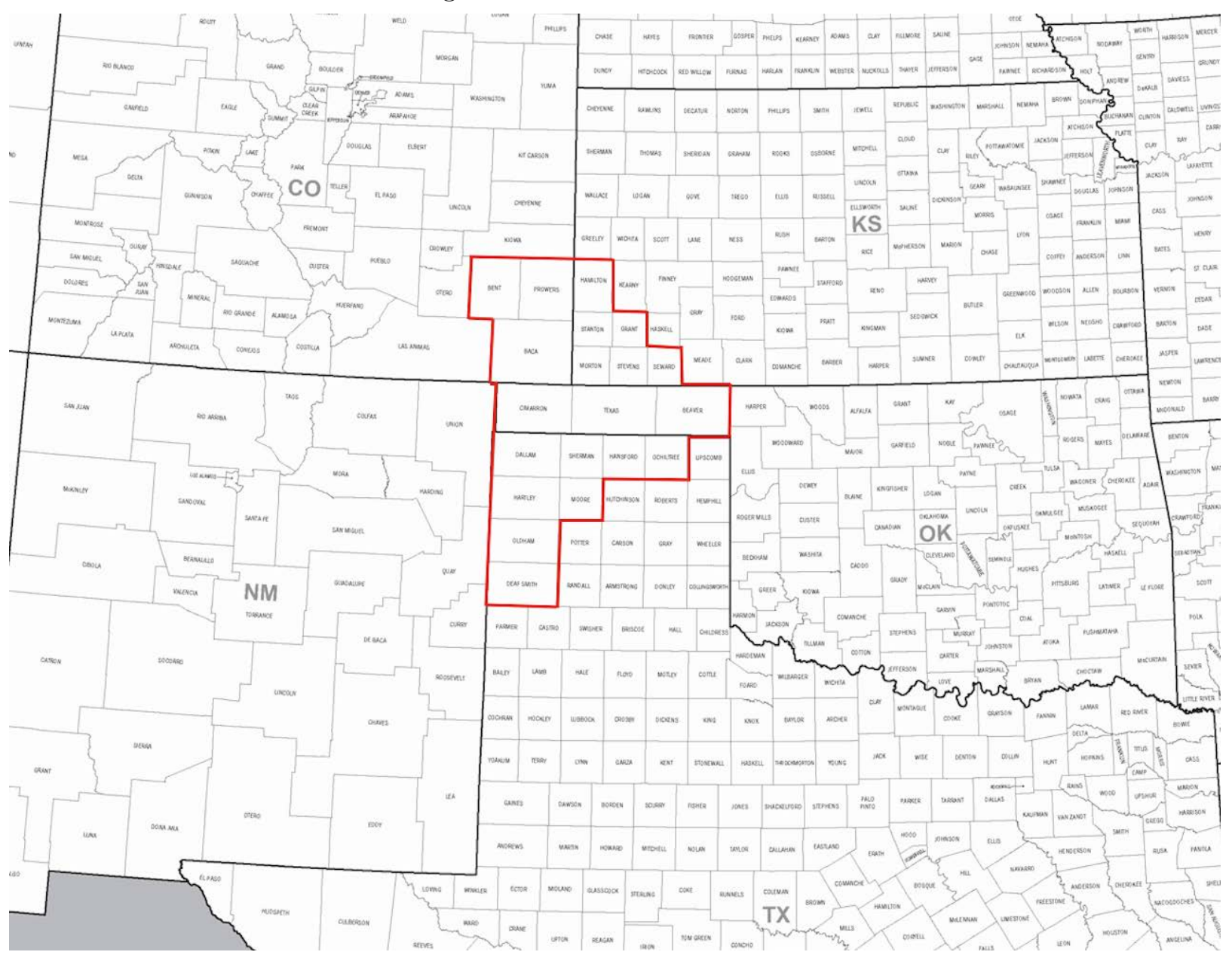

Notes: Most wind-eroded area, as identified by U.S. Department of Agriculture's Soil Conservation Service, in red. See text for details. Underlying county map from the U.S. Census Bureau.

in Kansas; Beaver, Cimarron, Texas in Oklahoma; and Dallam, Deaf Smith, Hansford, Hartley, Moore, Ochiltree, Oldham, and Sherman in Texas. These counties are plotted in Figure 1.

We follow the SCS by defining the Dust Bowl counties as these twenty counties in Colorado, Kansas, Oklahoma, and Texas. ${ }^{5}$ The 4,210 observations in our Dust Bowl dataset constitute an $11 \%$ sample of heads most severely affected by the Dust Bowl. In comparing the population of these twenty counties between the 1930 and 1940 censuses, this region experienced a sharp $19.2 \%$ drop, from 120,859 to 97,606 . This compares with population growth of $4.8 \%$ experienced by the same four states as a whole, during the same decade.

\footnotetext{
${ }^{5}$ In 1937, the SCS added six additional counties in New Mexico to the list; see Joel (1937) for details. Because of the costly nature of the linkage procedure, we focus our attention to the original twenty counties, to ensure a rich density of observations within the region of analysis.
} 


\section{Migration Rates}

\subsection{Inter-County and Inter-State Migration}

The first question we address is how geographic mobility differed in the Dust Bowl region from elsewhere. Did residents of the most drought-affected and wind-eroded counties move at a higher rate than elsewhere? To answer this question we compute the fraction of residents in 1930 who were no longer living in the same place when surveyed in the 1940 census. In what follows, "place" will refer alternately to the geographic region of county and state. ${ }^{6}$

Table 1 summarizes these results. The first row presents the fraction of heads who migrated across counties between 1930 and 1940. The first column presents results for those living in a Dust Bowl county in 1930, the second column for those originating from all other counties in the U.S. ${ }^{7}$ As is obvious, the rate of inter-county migration was very high in the Dust Bowl: more than half $(51.6 \%)$ of all heads originating from such counties were residing in a different county in 1940. This was approximately 1.8 times that of the inter-county migration rate $(28.9 \%)$ observed in non-Dust Bowl counties.

This stark difference in mobility could simply reflect differences in rural/urban composition between the Dust Bowl region and elsewhere. While the Dust Bowl counties were largely rural, the U.S. population as a whole was split much more evenly between rural and urban locales. ${ }^{8}$ The third column of Table 1 presents statistics for non-Dust Bowl heads residing in rural areas in 1930. As indicated in the first row, only $28.3 \%$ of such individuals moved across county lines during the decade, a rate very similar to those from non-Dust Bowl counties as a whole. Hence, the high migration rates observed in the Dust Bowl were not shared by other rural populations.

While drought and erosion were experienced throughout the Great Plains, conditions were not as uniform in their severity when compared to our Dust Bowl region. Migration rates were also not as high. Of the 4335 observations in our non-Dust Bowl sample, 540 were residing in the Plains states (of Montana, Wyoming, Colorado, New Mexico, North Dakota, South Dakota, Nebraska, Kansas, Oklahoma, and Texas-but outside of the twenty Dust Bowl counties) in 1930. Though not presented in Table 1, the inter-county migration rate between 1930 and 1940 for this subsample was $36.8 \%$, a value closer to those observed outside of the Dust Bowl than within it.

\footnotetext{
${ }^{6}$ The 1940 census also asked individuals of their place of residence in 1935, allowing us to consider geographic mobility at the 5-year frequency; see below for analysis. However, given the nature of the data, we are unable to observe multiple moves within 5-year time intervals.

${ }^{7}$ The Non-Dust Bowl sample, in fact, refers to the nationally-representative sample. In 1930, the population of the Dust Bowl counties represented $0.1 \%$ of the total U.S. population. The construction of the 4,335 observations in the national sample yielded two observations from the Dust Bowl, which were removed from the analysis.

${ }^{8}$ In the 1930 Census, $56.1 \%$ of the population resided in urban areas; within our sample of heads in Non-Dust Bowl counties, the urban share is $53.3 \%$.
} 
Table 1: Geographic Mobility Rates

\begin{tabular}{lcccc}
\hline \hline & $\begin{array}{c}\text { Dust Bowl } \\
1930-40\end{array}$ & $\begin{array}{c}\text { Non-Dust Bowl } \\
1930-40\end{array}$ & $\begin{array}{c}\text { Rural Non-DB } \\
1930-40\end{array}$ & $\begin{array}{c}\text { Dust Bowl } \\
1920-30\end{array}$ \\
\hline inter-county & $51.6 \%$ & $28.9 \%$ & $28.3 \%$ & $47.2 \%$ \\
inter-state & $33.5 \%$ & $13.9 \%$ & $12.2 \%$ & $31.2 \%$ \\
no. of obs. & 4210 & 4335 & 2024 & 2090 \\
\hline \hline
\end{tabular}

Notes: Mobility rates represent migration rates from sample of male household heads residing in Dust Bowl counties in 1930 and 1920 (cols. 1 and 4) and all other U.S. counties in 1930 (cols. 2 and 3). See text for details.

The fourth column presents statistics for heads in the same twenty counties as in column 1, but residing there in 1920. Though wheat prices had fallen from their peak during the First World War, the 1920s was a period of expansion in the Southern Plains, as good growing conditions and increasing mechanization led to higher yields and agricultural output (see, for instance, Worster (1979)). This led to a population boom during the 1920s: in the counties most severely affected by the Dust Bowl a decade later, the population had grown from 97,473 in 1920 to 120,859 in 1930. During this period of extraordinary population growth, the region exhibited an inter-county migration rate of $47.2 \%$. Hence, the high rates of mobility in the Dust Bowl relative to the rest of the U.S. was characteristic of the region, and not necessarily symptomatic of the hardships experienced in the 1930s.

The second row of Table 1 presents the inter-state migration rate. Given data limitations of previous studies, this coarser measure of geographic mobility has been the subject of analysis in other work (see, for example, Rosenbloom and Sundstrom (2004)). As with inter-county migration, inter-state migration was much higher in the Dust Bowl. Approximately 33.5\% of heads originating from a Dust Bowl county in 1930 had moved to a different state by 1940, a rate nearly 2.5 times that of heads in all other counties, rural or otherwise. In the $1920 \mathrm{~s}$, the inter-state migration rate in this region was, again, similarly high $(31.2 \%)$.

\subsection{Where Did They Move?}

Given the high rates of mobility, where did Dust Bowl migrants go? Did their migration patterns differ from those originating elsewhere? Did they differ from those originating from the same place a decade earlier? What was the role of out-migration in the depopulation of the Dust Bowl?

To make progress on these questions, Table 2 presents the fraction of inter-county migrants residing in specific locations in the terminal year census. The first row of column 1 indicates, perhaps surprisingly, that of the Dust Bowlers who made an inter-county move, $11.6 \%$ simply 
Table 2: Migration Destinations Probabilities

\begin{tabular}{lcc}
\hline \hline & $\begin{array}{c}\text { Dust Bowl } \\
1930-40\end{array}$ & $\begin{array}{c}\text { Dust Bowl } \\
1920-30\end{array}$ \\
\hline another DB county & $11.6 \%$ & $18.6 \%$ \\
DB state, non-DB county & $51.3 \%$ & $50.7 \%$ \\
non-DB state & $37.1 \%$ & $30.7 \%$ \\
\hline \hline
\end{tabular}

Notes: Destinations probabilities represent fraction of inter-county migrants residing in each location category in the terminal year census. See text for details.

moved to one of the other Dust Bowl counties. The first row of the second column presents the same statistic for migrants from the region, ten years prior. Of all inter-county migrants in the $1920 \mathrm{~s}, 18.6 \%$ moved to one of the other nineteen counties. Hence, compared to the 1930s, a greater fraction of the mobility represented "churning" or turnover within the region during the 1920s. By contrast, more of the mobility represented "exodus" or out-migration from the region during the Dust Bowl.

Nonetheless, the depopulation of the Dust Bowl was not due to an extraordinary exodus relative to historical norms. Between 1930 and 1940, given the inter-county migration rate of $51.6 \%$, the out-migration rate from the Dust Bowl was $0.516 \times(1-0.116)=45.6 \%$. Between 1920 and 1930, the out-migration rate from the same region was only slightly lower at $38.4 \%$. As such, the Dust Bowl depopulation was due largely to a sharp fall in the flow of in-migrants. Given these out-migration rates, and the Census Bureau's data on fertility and mortality, we are able to provide estimates on in-migration to the region (see Appendix B for details). Expressed relative to the source year population of the twenty counties in question, the in-migration rate between 1920 and 1930 was approximately $47.3 \%$; during the 1930s, the in-migration rate plummeted to about $15.5 \%$.

A simple counterfactual exercise puts these numbers in perspective. The population of the Dust Bowl fell from 120,859 in 1930 to 97,606 in 1940. Holding constant the number of births, deaths, and in-migrants at their observed 1930s values, if the out-migration rate from the Dust Bowl had equaled its 1920s value, the population in 1940 would have been 106,308. Lowering out-migration to its rate in the previous decade would not have prevented a population decline. By contrast, holding the number of births, deaths, and out-migrants constant at 1930s values, had the in-migration rate equaled its 1920s value, the population in 1940 would have increased to 136,079. Hence, the depopulation of the Dust Bowl was due primarily to the fall in in-migration. ${ }^{9}$

\footnotetext{
${ }^{9}$ Prior to this study, representative data allowing for the decomposition of the role of in- and out-migration to the 1930s depopulation did not exist. Nevertheless, the historian James C. Malin had conjectured that population decline experienced in Kansas between 1930 and 1935 was due to a fall in in-migration. In particular, Malin (1935) and Malin (1961) find a decrease in the turnover of farm operators in 1930-35, relative to 1925-30, in a sample of 48 Kansas townships, as documented in the state census farm schedule records (see also Geoff Cunfer's summary
} 
Figure 2: Histogram of Migration Distances

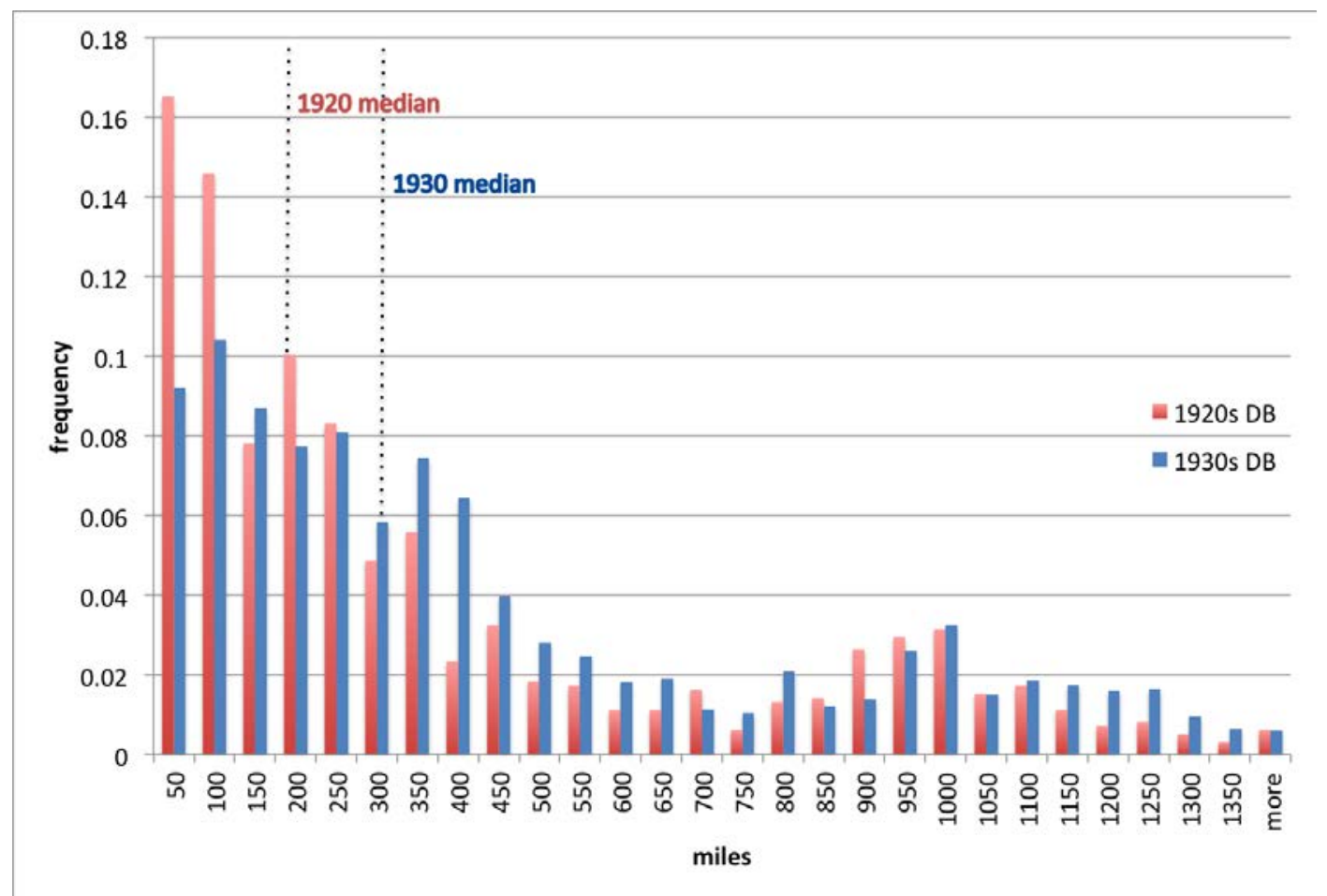

Notes: Distances measured in miles "as the crow flies" from respective county centroids. See text for details.

Returning to Table 2, taking the first two rows together, $62.9 \%$ of the Dust Bowl migrants were still residing in one of the Dust Bowl states (of Colorado, Kansas, Oklahoma, Texas) in 1940. Only $37.1 \%$ of all migrants left those four states. This indicates that Dust Bowl movers did not move "too far." 10 During the 1920s, 30.7\% of inter-county migrants left the four Dust Bowl states. Hence, the probability of leaving the Southern Plains was only slightly higher during Dust Bowl.

To better quantify the proximity of Dust Bowl relocations, we calculate the physical distance of moves for inter-county migrants. We measure this "as the crow flies," from the centroids of the county of residence in the source year and terminal year censuses. Figure 2 presents the histogram of migration distances for both decades.

Inter-county migrants from the Dust Bowl tended to make slightly longer moves, relative

of Malin's work in EH.net). Malin's conjecture was based on an extrapolation of the patterns in farm operator turnover as representative of population out-migration. Our findings confirm this conjecture for a comprehensive, random-sample of individuals for the Dust Bowl region, for the entire 1930s decade.

${ }^{10}$ Citing data from U.S. Bureau of the Census (1946), Worster (1979) also noted that, at the state level, a large fraction (46\%) of inter-state migrants from Oklahoma between 1935 and 1940 moved to a contiguous state. This is consistent with other evidence from the 1930s that farmers, in general, tended not to move too far; see Kraenzel (1939) for evidence from Montana, and Barton and McNeely (1939) for evidence from Arkansas. See also Taeuber and Hoffman (1937) on the prevalence of local moves on the Great Plains, gleaned from Farm Security Administration and other "scattered reports." 
to their regional counterparts from the previous decade. The median migration distance in the 1930s was 300 miles; in the 1920s, the median distance was 205 miles. By way of comparison, this difference is less than the 166 mile width (measured east-to-west) of the Oklahoma and Texas panhandles.

The tendency for longer moves in the 1930s is evident essentially throughout the distance distribution. The interquartile range during the Dust Bowl was 130-600 miles, compared to 70-500 miles during the 1920s. At the 90th percentile, the distances converge at approximately 1000 miles; this is the distance required, for example, to move from the centroid of the Dust Bowl region to Kern County, California, at the southern tip of the agriculturally-intensive San Joaquin Valley.

To visualize this, Figure 3 displays a heat map of the terminal year county of residence for inter-county migrants from the region. The top panel displays the 1940 location data for the Dust Bowl migrants, while the bottom panel displays the 1930 location data for the 1920s migrants. Darker colors indicate locations of greater migration incidence, lighter colors the opposite.

Migrants in the 1920s tended to move to counties within, or very close to, the Dust Bowl region: destination locations are concentrated in southeastern Colorado, southern Kansas, and the panhandles of Oklahoma and Texas. Migration destinations were more dispersed in the 1930s, with noticeably lower concentration within the Dust Bowl counties. Instead, migrants moved to western portions of Colorado, central Oklahoma, south of the Texas panhandle, as well as New Mexico and Missouri with greater frequency. ${ }^{11}$ This corroborates the results presented in Table 2 and Figure 2: while the median migrant moved approximately 100 miles further in the 1930s compared to the 1920s, this additional distance did not translate into moves outside of the Dust Bowl states or their adjacent states with much greater frequency.

A widely held perception - made popular, in part, by Steinbeck's Joad Family - is that Dust Bowl migrants moved to California en masse. While a powerful image, it is far from accurate. The results presented in Figures 2 and 3 indicate that relatively few made such a drastic move. ${ }^{12}$

\footnotetext{
${ }^{11}$ Figure 4 in Appendix A "zooms in" on the states of Colorado, Kansas, Oklahoma, Texas, and New Mexico to make these points more visually apparent. See also Lane (1938) and McMillan (1936) for discussion of migration to western Colorado and central Oklahoma, respectively; while these authors noted the arrival of Dust Bowlers to these regions, data were not available to them to document its prevalence or importance.

${ }^{12}$ Despite the intense interest in the topic, data on migration from the Dust Bowl to California was severely lacking prior to this study, and perhaps best expressed by Worster (1979) in his summary that "exact numbers are not wholly reliable." Research by the U.S. Resettlement Administration analyzed reports from the California Department of Agriculture, whose quarantine inspectors took note of vehicles entering the state whose occupants were "persons in need of manual employment" during 1935-36 (see Taylor and Vasey (1936) and Rowell (1936)). Based on license plate counts, a large fraction of in-migrants to California arrived from Southern drought states. Using survey data elicited from children enrolling in public schools for the first time, Hoffman (1938) and Janow (1940) also found that migrants to Oregon and California, respectively, were disproportionately from the Plains states. Such data, of course, could not determine the probability that a migrant moved to California, from the perspective of the source location, and hence does not shed light on the propensity of migrants to choose California over other destinations. Webb and Brown (1938) provide evidence on this propensity, but for the highly selected group of inter-state migrants receiving assistance from the transient bureaus of the Federal Emergency Relief
} 
Figure 3: Heat Map of Migration Destinations

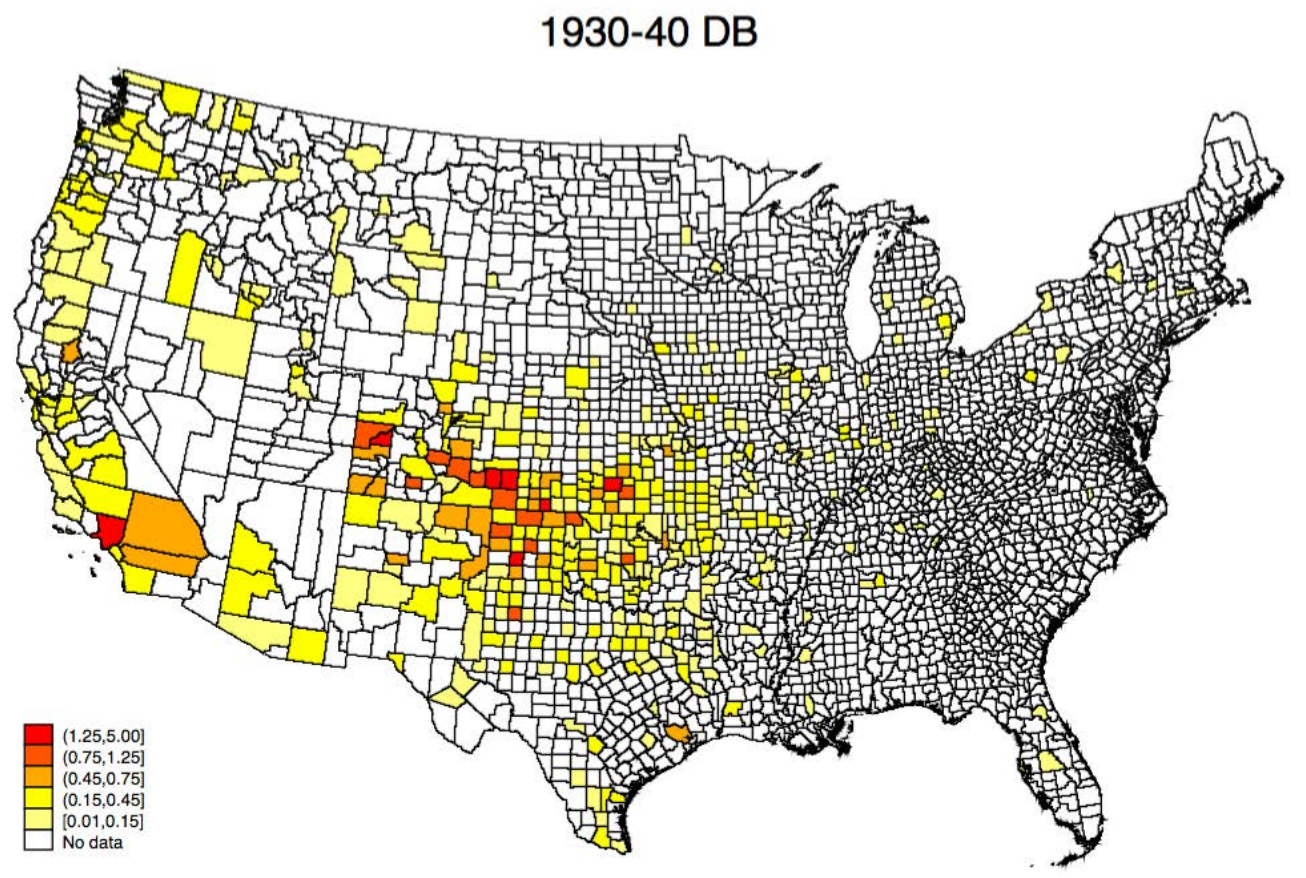

1920-30 DB

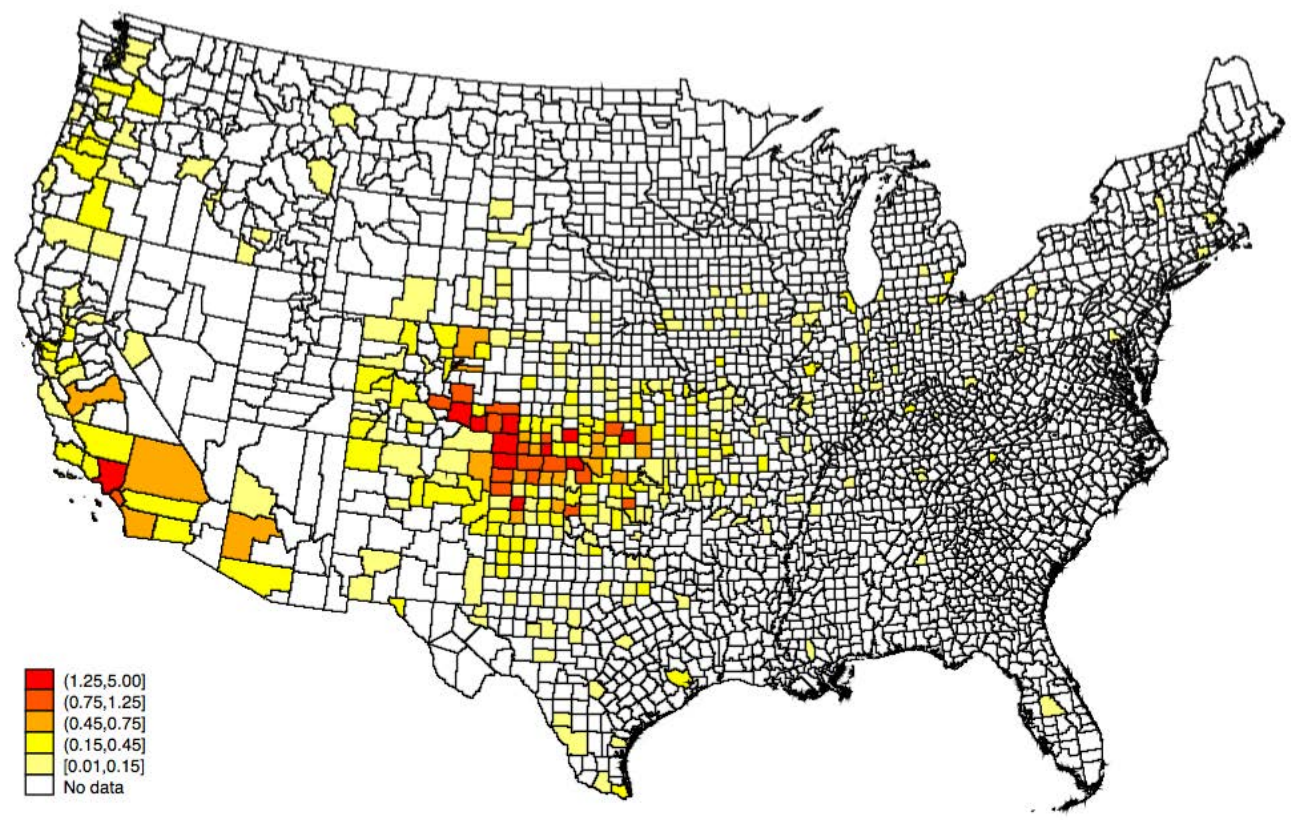

Notes: Darker (red) colors indicate locations of greater migration incidence from the Dust Bowl region, lighter (yellow) colors indicate the opposite. See text for details. 
Table 3: Migration Destinations Probabilities

\begin{tabular}{lcccc}
\hline \hline & $\begin{array}{c}\text { Dust Bowl } \\
1930-40\end{array}$ & $\begin{array}{c}\text { Non-Dust Bowl } \\
1930-40\end{array}$ & $\begin{array}{c}\text { Rural Non-DB } \\
1930-40\end{array}$ & $\begin{array}{c}\text { Dust Bowl } \\
1920-30\end{array}$ \\
\hline California & $9.82 \%$ & $7.54 \%$ & $7.39 \%$ & $10.9 \%$ \\
cond. on state move & $15.1 \%$ & $15.6 \%$ & $17.1 \%$ & $16.8 \%$ \\
\hline \hline
\end{tabular}

Notes: Destinations probabilities represent fraction of inter-county migrants residing in each location category in terminal year, except as noted in second row. See text for details.

Table 3 provides greater context. As indicated in the first row, less than ten percent of intercounty migrants moved to California. Dust Bowl migrants were in fact more likely to move to another Dust Bowl county. Moreover, the rate at which the Okies moved to California (9.82\%) was largely similar to that of migrants from elsewhere in the country $(7.54 \%)$ during the 1930s (the latter statistic excludes those living in California in 1930). The second row illustrates this from a slightly different perspective: it indicates the fraction of movers who went to California, conditional on an inter-state move. This probability was virtually identical for those from the Dust Bowl and everywhere else. This is true despite the fact that the vast majority of non-Dust Bowl migrants originated from places substantially further to the east and/or north.

Comparing the first and fourth columns of Table 3 indicate that migration to California from the Dust Bowl was also similar to that experienced from the region in the 1920s. The probability of moving to California, given either an inter-county or an inter-state move, was actually greater in the previous decade. In results not reported in Table 3, we find that, conditional on an inter-county move, the fraction of Dust Bowl migrants who moved to any of the west coast states of California, Oregon, and Washington was 14.9\%; in the 1920s, the fraction of migrants moving to the west coast was $13.9 \%$. Finally, we compute the longitudinal direction of moves using the centroids of the county of residence in the source and terminal year censuses. In the 1930s, $45.9 \%$ of migrants from the Dust Bowl moved in a westerly direction relative to their 1930 location. This compares with $45.6 \%$ in the previous decade. As such, our data indicate that the "westward push" from the Dust Bowl was unexceptional during the 1930s.

Administration during 1934-1935. Of the approximately 5500 migrant families in their sample, $20 \%$ moved to California. FERA data specific to the Dust Bowl is not available, but of the migrant families from the four Dust Bowl states, $31 \%$ moved to California. The Census Bureau's previously released data are also incomplete, as they cover only the period 1935-1940; with respect to their published reports, U.S. Bureau of the Census (1946) provides only migration flows for source states to the various census divisions (e.g., from Oklahoma to the Pacific division), without any information on migration destination at the state- or county-level. 
Table 4: Migration Patterns, $1930 \rightarrow 1935 \rightarrow 1940$

\begin{tabular}{|c|c|}
\hline & fraction \\
\hline$A \rightarrow A \rightarrow B$ & $25.4 \%$ \\
\hline$A \rightarrow B \rightarrow B$ & $52.8 \%$ \\
\hline \multicolumn{2}{|l|}{$A \rightarrow C \rightarrow B$} \\
\hline$C$ is DB county & $3.83 \%$ \\
\hline$C$ is non-DB county & $18.1 \%$ \\
\hline no. of obs. & 1933 \\
\hline
\end{tabular}

Notes: Migration patterns represent fraction of inter-county migrants, originating from the Dust Bowl, by location of residence in 1935. See text for details.

\subsection{When Did They Move?}

The 1940 Census was the first U.S. census to ask respondents of their location of residence five years ago, in 1935. Given that this information was self-reported, it is less accurate relative to the respondents' information for 1930 or 1940 along two key dimensions: (i) whether the "five years ago" information pertained precisely to the year 1935, and (ii) whether the name and spelling of the county of residence were reported and recorded correctly.

Nonetheless, this information allows us to determine how geographic mobility in the Dust Bowl was approximately distributed across the early and latter parts of the decade. This is of interest, given that the economic and environmental effects of the Dust Bowl were felt throughout the 1930s, with many of the agriculture-related New Deal programs - the Emergency Farm Mortgage Act, Farm Credit Act, and Agricultural Adjustment Act in 1933; establishment of the Resettlement Administration (later the Farm Security Administration) and Soil Conservation Service in 1935 - initiated in the early-to-mid portions of the decade.

Table 4 indicates the location patterns of Dust Bowl migrants between 1930 and 1940, for those whose location of residence in 1935 could be accurately discerned. In the table, we denote the county of origin in 1930 by the letter $A$, and the destination county in 1940 by the letter $B$. The first row indicates that approximately one quarter of Dust Bowl migrants were still living in their county of origin in 1935 . By contrast, $52.8 \%$ had already moved to their destination county by 1935. Rows three and four indicate the fraction of migrants who were in a third location, $C$, in 1935 (that was neither their 1930 nor 1940 residence). A non-negligible fraction (21.8\%) made an "indirect" move between points $A$ and $B$ during the decade. Hence, the vast majority of Dust Bowl migrants had already moved by mid-decade.

This fact is particularly interesting, given that prior to this study, data on migration spanning 
the entire decade was unavailable. Indeed, the literature's conclusions on Dust Bowl migration are based largely on the 1935 and 1940 location data obtained from the 1940 Census (see, for instance, Worster (1979)). The results in Table 4 indicate that $52.8+18.1=70.9 \%$ of the observations on inter-county migration that we identify through census linkage would have been missed by simply using the 1935 location of residence information from the 1940 Census. ${ }^{13}$

\section{Who Moved and Why?}

As documented in Section 3, migration rates were much higher among Dust Bowlers compared to other Americans. In this section, we investigate the determinants of mobility using data on individual-level and county-level characteristics available from the census and other sources. ${ }^{14}$ We also use standard decomposition techniques to determine the extent to which differences in mobility across Dust Bowl and other regions were due to differences in demographic characteristics or differences in propensities for migration.

\subsection{Determinants of Geographic Mobility}

\subsubsection{Inter-County and Inter-State Migration}

We begin by analyzing how inter-county migration probabilities covaried with individual characteristics. Let $\pi_{i}$ be a dummy variable that takes on the value of 1 if individual $i$ moves across counties between 1930 and 1940, and a value of 0 otherwise. To begin, we consider a simple linear probability model for migration:

$$
\pi_{i}=X_{i} \beta+\epsilon_{i}
$$

where, $X_{i}$ denotes characteristics of individual $i$ in 1930 .

Included in $X_{i}$ are standard demographic controls for age, marital status, and years of schooling. ${ }^{15}$ The 1930 Census also allows us to determine whether an individual: is a "head of family" or "other household head" (e.g., boarder, lodger); owns or rents his home; is living in his

\footnotetext{
${ }^{13}$ Of course, our linkage methodology misses migrants who were not living in the Dust Bowl in 1930, moved there by 1935, and moved again by 1940. Given the low rate of in-migration that is necessary to account for the region's depopulation, the number of such observations is likely to be small relative to those that we capture.

${ }^{14}$ For analysis of individual-level determinants of migration in the modern-day (1981-2010) context, see Molloy et al. (2011), and the references therein.

${ }^{15}$ We do not include information on race in our analysis, since there exists almost no variation in race in the Dust Bowl counties. Of the Dust Bowl heads enumerated by the census in 1930, 99.6\% were white. Information on education was obtained from the 1940 census, so our assumption is that education observed in 1940 was attained prior to 1930. Given that our sample includes heads aged $16-60$ in 1930, we drop individuals for which (years of schooling +5$)>($ age in 1930) from our regression analysis. We use this information to generate a categorical variable for whether an individual has attended: less than 8 years of school, exactly 8 years (primary school graduate), high school (9-12 years), or at least one year of post-secondary education (13+ years).
} 
birth state or not. In terms of parental information, we can determine the number of children, and the age of each child belonging to the head. In our benchmark specification, we include a dummy variable for whether a child under the age of 5 years is present in the household; based on our analysis of various ways to control for parenthood, this contained the most explanatory power. We also include the individual's 1930 occupational information. Not surprisingly, the distribution of occupations in the Dust Bowl differs quite dramatically from that of our non-Dust Bowl sample, and in particular, from the distribution observed in urban areas. For purposes of comparison, we choose to summarize the occupational information into four broad, mutually exclusive categories: farmers who are, by definition, self-employed; farm laborers who are, by definition, wage workers; non-farm self-employed; and non-farm wage workers. ${ }^{16}$

The first column of Table 5 presents results for the representative sample of heads residing in non-Dust Bowl counties in 1930. The excluded group in the regression are heads who are: 46-60 years old, single, with no children under 5, not living in their state of birth, with fewer than 8 years of (primary) schooling, not a family head, renters, and farmers.

The estimated coefficients are all of the expected sign and relative magnitudes. For instance, there is a strong negative relationship between age and mobility, with 16-25 year olds 17.4 percentage points more likely, and 26-35 year olds $5.1 \mathrm{pp}$ more likely (both significant at the $1 \%$ level) to move counties relative to $46-60$ year olds. ${ }^{17}$ Not surprisingly, being the head of a family, being married, and having young children - covariates that we refer to as "family structure" hereafter - have very strong and statistically significant negative effects on migration probability. Home owners and those living in their state of birth are less likely to move, and all of these effects are significant at the $1 \%$ level. There is no statistically significant relationship between occupational group and inter-county migration probability. Finally, mobility tends to be increasing in education when one compares the lowest to the highest attainment level. ${ }^{18}$

The second column of Table 5 presents the results for the Dust Bowl counties. Qualitatively, the results are similar to those for the non-Dust Bowl sample. There are, however, important differences. First, there is no statistically significant relationship between education and mobility; if anything, the probability of migration falls with greater levels of attainment.

Second, the effects of the family structure covariates are substantially weaker in the Dust Bowl. The point estimate for being married is near zero; the point estimate is actually positive for having young children (both are statistically insignificant). By contrast, these variables are associated with significantly lower migration probabilities elsewhere. These family structure

\footnotetext{
${ }^{16}$ See Section 5 for analysis that uses the occupational information in a much richer manner.

${ }^{17}$ In analysis not presented here, we further split the 46-60 year old group into 46-55 year olds and 56-60 year olds. Because none of the estimated coefficients were statistically distinguishable between these two groups, we chose the more parsimonious specification presented here.

${ }^{18}$ In Census data from 1940 onward, Rosenbloom and Sundstrom (2004) also find a positive relationship between education and mobility.
} 
Table 5: Determinants of Inter-County Migration: Regression Results

\begin{tabular}{|c|c|c|c|c|c|c|}
\hline & \multicolumn{3}{|c|}{ Benchmark } & \multicolumn{3}{|c|}{ Extended } \\
\hline & $\begin{array}{c}\text { Non- } \\
\text { Dust Bowl }\end{array}$ & $\begin{array}{l}\text { Dust } \\
\text { Bowl }\end{array}$ & $\begin{array}{c}\text { Rural } \\
\text { Non-DB }\end{array}$ & $\begin{array}{c}\text { Non- } \\
\text { Dust Bowl }\end{array}$ & $\begin{array}{l}\text { Dust } \\
\text { Bowl }\end{array}$ & $\begin{array}{c}\text { Rural } \\
\text { Non-DB }\end{array}$ \\
\hline constant & $\begin{array}{c}0.679 \\
(0.0402)\end{array}$ & $\begin{array}{c}0.644 \\
(0.0373)\end{array}$ & $\begin{array}{c}0.635 \\
(0.0614)\end{array}$ & $\begin{array}{c}0.687 \\
(0.0418)\end{array}$ & $\begin{array}{c}0.620 \\
(0.0411)\end{array}$ & $\begin{array}{c}0.650 \\
(0.0641)\end{array}$ \\
\hline $\begin{array}{l}a g e \\
16-25 \text { yrs }\end{array}$ & $\begin{array}{c}0.174 \\
(0.0404)\end{array}$ & $\begin{array}{c}0.156 \\
(0.0291)\end{array}$ & $\begin{array}{c}0.185 \\
(0.0573)\end{array}$ & $\begin{array}{c}0.168 \\
(0.0408)\end{array}$ & $\begin{array}{c}0.161 \\
(0.0312)\end{array}$ & $\begin{array}{c}0.176 \\
(0.0581)\end{array}$ \\
\hline $26-35$ yrs & $\begin{array}{l}0.0514 \\
(0.0196)\end{array}$ & $\begin{array}{l}0.0506 \\
(0.0228)\end{array}$ & $\begin{array}{l}0.0725 \\
(0.0283)\end{array}$ & $\begin{array}{l}0.0479 \\
(0.0199)\end{array}$ & $\begin{array}{l}0.0557 \\
(0.0242)\end{array}$ & $\begin{array}{l}0.0676 \\
(0.0288)\end{array}$ \\
\hline $36-45$ yrs & $\begin{array}{l}0.0224 \\
(0.0165)\end{array}$ & $\begin{array}{l}0.0301 \\
(0.0208)\end{array}$ & $\begin{array}{l}0.0527 \\
(0.0239)\end{array}$ & $\begin{array}{l}0.0191 \\
(0.0168)\end{array}$ & $\begin{array}{l}0.0346 \\
(0.0218)\end{array}$ & $\begin{array}{l}0.0469 \\
(0.0243)\end{array}$ \\
\hline family head & $\begin{array}{l}-0.220 \\
(0.0444)\end{array}$ & $\begin{array}{l}-0.131 \\
(0.0395)\end{array}$ & $\begin{array}{l}-0.207 \\
(0.0736)\end{array}$ & $\begin{array}{l}-0.216 \\
(0.0448)\end{array}$ & $\begin{array}{l}-0.100 \\
(0.0429)\end{array}$ & $\begin{array}{l}-0.200 \\
(0.0744)\end{array}$ \\
\hline married & $\begin{array}{l}-0.103 \\
(0.0369)\end{array}$ & $\begin{array}{r}-0.0165 \\
(0.0345)\end{array}$ & $\begin{array}{r}-0.0795 \\
(0.0546)\end{array}$ & $\begin{array}{r}-0.0946 \\
(0.0372)\end{array}$ & $\begin{array}{r}-0.0132 \\
(0.0364)\end{array}$ & $\begin{array}{r}-0.0843 \\
(0.0553)\end{array}$ \\
\hline young child & $\begin{array}{r}-0.0475 \\
(0.0173)\end{array}$ & $\begin{array}{l}0.0244 \\
(0.0178)\end{array}$ & $\begin{array}{r}-0.0560 \\
(0.0247)\end{array}$ & $\begin{array}{r}-0.0505 \\
(0.0175)\end{array}$ & $\begin{array}{l}0.0198 \\
(0.0188)\end{array}$ & $\begin{array}{r}-0.0542 \\
(0.0251)\end{array}$ \\
\hline in birthstate & $\begin{array}{r}-0.0972 \\
(0.0148)\end{array}$ & $\begin{array}{r}-0.0006 \\
(0.0181)\end{array}$ & $\begin{array}{r}-0.0920 \\
(0.0231)\end{array}$ & $\begin{array}{l}-0.102 \\
(0.0150)\end{array}$ & $\begin{array}{l}0.0029 \\
(0.0197)\end{array}$ & $\begin{array}{l}-0.101 \\
(0.0234)\end{array}$ \\
\hline $\begin{array}{l}\text { home owned } \\
\text { schooling }\end{array}$ & $\begin{array}{l}-0.128 \\
(0.0149)\end{array}$ & $\begin{array}{l}-0.208 \\
(0.0171)\end{array}$ & $\begin{array}{l}-0.152 \\
(0.0226)\end{array}$ & $\begin{array}{l}-0.123 \\
(0.0151)\end{array}$ & $\begin{array}{c}-0.192 \\
(0.0186)\end{array}$ & $\begin{array}{l}-0.151 \\
(0.0229)\end{array}$ \\
\hline primary grad & $\begin{array}{r}-0.0308 \\
(0.0177)\end{array}$ & $\begin{array}{l}0.0171 \\
(0.0194)\end{array}$ & $\begin{array}{r}-0.0191 \\
(0.0245)\end{array}$ & $\begin{array}{r}-0.0224 \\
(0.0182)\end{array}$ & $\begin{array}{l}0.0204 \\
(0.0207)\end{array}$ & $\begin{array}{r}-0.0147 \\
(0.0253)\end{array}$ \\
\hline high school & $\begin{array}{l}0.0145 \\
(0.0203)\end{array}$ & $\begin{array}{l}-0.0348 \\
(0.0218)\end{array}$ & $\begin{array}{l}0.0383 \\
(0.0303)\end{array}$ & $\begin{array}{l}0.0259 \\
(0.0209)\end{array}$ & $\begin{array}{c}-0.0328 \\
(0.0233)\end{array}$ & $\begin{array}{l}0.0443 \\
(0.0313)\end{array}$ \\
\hline college & $\begin{array}{l}0.0512 \\
(0.0253)\end{array}$ & $\begin{array}{r}-0.0385 \\
(0.0287)\end{array}$ & $\begin{array}{l}0.0627 \\
(0.0412)\end{array}$ & $\begin{array}{l}0.0638 \\
(0.0258)\end{array}$ & $\begin{array}{c}-0.0294 \\
(0.0304)\end{array}$ & $\begin{array}{l}0.0787 \\
(0.0416)\end{array}$ \\
\hline $\begin{array}{l}\text { occupation } \\
\text { farm labor }\end{array}$ & $\begin{array}{l}0.0736 \\
(0.0490)\end{array}$ & $\begin{array}{c}0.112 \\
(0.0316)\end{array}$ & $\begin{array}{l}0.0647 \\
(0.0529)\end{array}$ & $\begin{array}{l}0.0734 \\
(0.0489)\end{array}$ & $\begin{array}{c}0.108 \\
(0.0338)\end{array}$ & $\begin{array}{l}0.0630 \\
(0.0531)\end{array}$ \\
\hline non-farm wage & $\begin{array}{l}0.0029 \\
(0.0182)\end{array}$ & $\begin{array}{c}0.124 \\
(0.0184)\end{array}$ & $\begin{array}{l}0.0183 \\
(0.0235)\end{array}$ & $\begin{array}{l}0.0119 \\
(0.0191)\end{array}$ & $\begin{array}{c}0.127 \\
(0.0198)\end{array}$ & $\begin{array}{l}0.0138 \\
(0.0244)\end{array}$ \\
\hline non-farm SE & $\begin{array}{r}-0.0122 \\
(0.0238)\end{array}$ & $\begin{array}{l}0.0525 \\
(0.0261)\end{array}$ & $\begin{array}{r}-0.0087 \\
(0.0341)\end{array}$ & $\begin{array}{r}-0.0029 \\
(0.0245)\end{array}$ & $\begin{array}{l}0.0616 \\
(0.0277)\end{array}$ & $\begin{array}{c}-0.0074 \\
(0.0351)\end{array}$ \\
\hline own radio & & & & $\begin{array}{c}-0.0534 \\
(0.0153)\end{array}$ & $\begin{array}{r}-0.0950 \\
(0.0189)\end{array}$ & $\begin{array}{r}-0.0226 \\
(0.0224)\end{array}$ \\
\hline parent birthstate & & & & $\begin{array}{c}-0.0143 \\
(0.0156)\end{array}$ & $\begin{array}{c}0.0038 \\
(0.0165)\end{array}$ & $\begin{array}{r}-0.0048 \\
(0.0231)\end{array}$ \\
\hline$R^{2}$ & 0.115 & 0.113 & 0.125 & 0.120 & 0.121 & 0.125 \\
\hline observations & 4185 & 3961 & 1952 & 4052 & 3506 & 1898 \\
\hline
\end{tabular}

Notes: Coefficient estimates from the linear probability model, equation (1). See text for details on variables. Standard errors in parentheses. 
covariates measure costs of migration. Under this interpretation, these costs were viewed as less relevant - compared to the benefit of moving - for those living in the Dust Bowl.

Similarly, one can view the variable indicating whether one is living in his state of birth as measuring a cost of migration. Living in one's birth state likely means having greater family and/or economic ties to the place of residence. While living in one's birth state has a strong negative effect on migration probability outside of the Dust Bowl, it has no effect in the Dust Bowl. This indicates that Dust Bowl residents viewed this cost as being of no relevance, compared to the benefit of moving.

By contrast, there are a number of covariates that have stronger effects in the sample of Dust Bowl heads. Being a home-owner has a much stronger negative effect on mobility. Relative to all other occupations, the (excluded group of) farmers have a lower probability of moving. These effects are large and statistically significant at either the $1 \%$ or $5 \%$ level. Hence, of all occupations, farmers were the least likely to move from the Dust Bowl. This may seem unsurprising if farmers are those who possess the most location-specific human and physical capital. However, to the extent that this is true, this effect is not borne out for farmers anywhere else in the country: as evidenced in columns 1 and 3 (to be discussed below), all occupation groups have statistically indistinguishable probabilities of migration outside of the Dust Bowl. The relative immobility of farmers is unique to the Dust Bowl region. This finding is surprising given our cultural notion of the migrant Dust Bowl farmer expelled from the land, as portrayed in literature, art, and music.

In the third column of Table 5, we consider the sample of heads in rural, non-Dust Bowl counties. As discussed in Section 3, the high rates of migration observed in the Dust Bowl were not shared by other rural areas. In the context of this regression analysis, the objective is to determine whether the differences in the effects of various covariates across samples are also evident when comparing the Dust Bowl with other rural areas.

Indeed, we find that the estimated differences remain. The regression results for the rural non-Dust Bowl sample are largely the same as the non-Dust Bowl sample that includes both urban and rural heads. Hence, the differences in the determinants of migration observed in the Dust Bowl relative to outside the Dust Bowl are not shared by other rural populations.

In the three rightmost columns of Table 5 , we consider robustness of our results by extending the set of individual-level covariates included in our migration probability model. The 1930 Census includes information on the birth state of an individual's parents. With this, we construct a dummy variable for whether the head's birth state differs from that of both parents. We view this as a measure of "inherited family mobility." The 1930 Census also contains information on whether a head owned a radio set. We include this information in the extended specification as both a proxy for wealth and access to news/information. 
Comparing column 1 to 4 (and 2 to 5 , and 3 to 6 ), the results for the variables included in the benchmark specification are extremely robust to this modification, as the coefficient estimates and their significance are essentially unchanged. Regarding the additional variables themselves, being born in a state different from both parents' birth state has no additional predictive power. By contrast, columns 4 and 5 indicate a strong negative relationship between radio set ownership and mobility for both the Dust Bowl and non-Dust Bowl samples. If one were to interpret owning a radio as a proxy for wealth, it is interesting that a similar relationship emerges for home ownership: both variables exhibit a negative effect on migration, with the effect being nearly twice as strong in the Dust Bowl. ${ }^{19}$ Radio set ownership could also measure access to information about economic conditions. ${ }^{20}$ Under this interpretation, the negative effect of ownership could indicate that those more informed about the wide-reach of the Dust Bowl and Great Depression were less likely to believe migration would improve well-being.

\subsubsection{Additional Results}

We conduct a series of robustness checks which, for the sake of brevity, we present in Appendices $\mathrm{C}$ and D. First, we repeat the analysis on inter-county migration replacing the linear probability model, equation (1), with a probit model. In Table 13, we report the marginal effects estimated from this specification. Not surprisingly, the results are essentially identical to those generated from the linear specification. We also extend our analysis of inter-county migration by augmenting the individual-level covariates with a number of variables at the county-level, as considered in Fishback et al. (2006). ${ }^{21}$ This allows for an additional robustness check, and comparison of our results on gross migration (at the individual level) with their results on net migration (at the county level). This is discussed in Appendix D. In Table 14, we repeat the analysis of Table 5, this time considering the determinants of inter-state migration. Overall, the results for inter-state migration are similar to those for inter-county migration. The salient differences between Dust Bowl and non-Dust Bowl counties remain intact.

In Section 3, we document how inter-county and inter-state migration rates in the Dust Bowl region were similar when comparing the 1930s and 1920s decades. In this sense, the high mobility rates in the Dust Bowl relative to the rest of the U.S. was characteristic of the region. Here, we determine whether the influence of observables on migration choices were similar for inhabitants of the region across decades, or whether the estimated effects from Tables 5 and 14 were unique to the Dust Bowl episode.

Table 6 presents the results from the estimation of equation (1) on the Dust Bowl samples

\footnotetext{
${ }^{19}$ While owning relative to renting is a clear indication of wealth, home ownership is very likely associated with mobility through other channels. Transaction costs associated with selling a home is an obvious example.

${ }^{20}$ See, for instance, Ziebarth (2013) for evidence on the importance of radio set ownership on information dissemination during the Great Depression.

${ }^{21}$ We refer the reader to their paper for detailed description of data sources and the construction of the variables.
} 
Table 6: Determinants of Dust Bowl Region Migration: 1920s vs 1930s

\begin{tabular}{|c|c|c|c|c|c|c|}
\hline & \multicolumn{2}{|c|}{ Inter-County } & \multicolumn{2}{|c|}{ Inter-State } & \multicolumn{2}{|c|}{ Dust Bowl Exit } \\
\hline & $1920 \mathrm{~s}$ & $1930 \mathrm{~s}$ & $1920 \mathrm{~s}$ & $1930 \mathrm{~s}$ & $1920 \mathrm{~s}$ & $1930 \mathrm{~s}$ \\
\hline constant & 0.596 & 0.644 & 0.466 & 0.469 & 0.510 & 0.587 \\
\hline age & & & & & & \\
\hline $16-25$ yrs & $\begin{array}{l}0.0795 \\
(0.0434)\end{array}$ & $\begin{array}{c}0.146 \\
(0.0281)\end{array}$ & $\begin{array}{l}0.0899 \\
(0.0422)\end{array}$ & $\begin{array}{c}0.146 \\
(0.0287)\end{array}$ & $\begin{array}{l}0.0277 \\
(0.0433)\end{array}$ & $\begin{array}{c}0.131 \\
(0.0289)\end{array}$ \\
\hline 26-35 yrs & $\begin{array}{l}0.0829 \\
(0.0297)\end{array}$ & $\begin{array}{l}0.0484 \\
(0.0222)\end{array}$ & $\begin{array}{l}0.0846 \\
(0.0278)\end{array}$ & $\begin{array}{l}0.0590 \\
(0.0211)\end{array}$ & $\begin{array}{l}0.0640 \\
(0.0290)\end{array}$ & $\begin{array}{l}0.0361 \\
(0.0220)\end{array}$ \\
\hline $36-45$ yrs & $\begin{array}{l}0.0287 \\
(0.0283)\end{array}$ & $\begin{array}{l}0.0313 \\
(0.0204)\end{array}$ & $\begin{array}{l}0.0286 \\
(0.0257)\end{array}$ & $\begin{array}{l}0.0345 \\
(0.0190)\end{array}$ & $\begin{array}{l}0.0208 \\
(0.0275)\end{array}$ & $\begin{array}{l}0.0150 \\
(0.0200)\end{array}$ \\
\hline family head & $\begin{array}{l}-0.0927 \\
(0.0601)\end{array}$ & $\begin{array}{l}-0.133 \\
(0.0379)\end{array}$ & $\begin{array}{l}-0.118 \\
(0.0652)\end{array}$ & $\begin{array}{l}-0.143 \\
(0.0407)\end{array}$ & $\begin{array}{l}-0.143 \\
(0.0620)\end{array}$ & $\begin{array}{l}-0.157 \\
(0.0394)\end{array}$ \\
\hline married & $\begin{array}{l}0.0191 \\
(0.0411)\end{array}$ & $\begin{array}{r}-0.0135 \\
(0.0336)\end{array}$ & $\begin{array}{c}0.0051 \\
(0.0399)\end{array}$ & $\begin{array}{r}-0.0101 \\
(0.0329)\end{array}$ & $\begin{array}{l}0.0507 \\
(0.0395)\end{array}$ & $\begin{array}{r}-0.0078 \\
(0.0340)\end{array}$ \\
\hline young child & $\begin{array}{l}0.0416 \\
(0.0233)\end{array}$ & $\begin{array}{l}0.0260 \\
(0.0175)\end{array}$ & $\begin{array}{l}0.0261 \\
(0.0216)\end{array}$ & $\begin{array}{l}0.0257 \\
(0.0168)\end{array}$ & $\begin{array}{l}0.0134 \\
(0.0227)\end{array}$ & $\begin{array}{l}0.0265 \\
(0.0175)\end{array}$ \\
\hline in birthstate & $\begin{array}{c}-0.0714 \\
(0.0307)\end{array}$ & $\begin{array}{c}-0.0034 \\
(0.0177)\end{array}$ & $\begin{array}{l}-0.194 \\
(0.0259)\end{array}$ & $\begin{array}{l}-0.110 \\
(0.0169)\end{array}$ & $\begin{array}{r}-0.0650 \\
(0.0299)\end{array}$ & $\begin{array}{l}0.0008 \\
(0.0178)\end{array}$ \\
\hline home owned & $\begin{array}{l}-0.220 \\
(0.0243)\end{array}$ & $\begin{array}{l}-0.207 \\
(0.0168)\end{array}$ & $\begin{array}{l}-0.140 \\
(0.0233)\end{array}$ & $\begin{array}{l}-0.121 \\
(0.0159)\end{array}$ & $\begin{array}{l}-0.174 \\
(0.0242)\end{array}$ & $\begin{array}{l}-0.181 \\
(0.0166)\end{array}$ \\
\hline $\begin{array}{l}\text { occupation } \\
\text { farm labor }\end{array}$ & $\begin{array}{c}0.168 \\
(0.0456)\end{array}$ & $\begin{array}{c}0.114 \\
(0.0313)\end{array}$ & $\begin{array}{l}0.0458 \\
(0.0504)\end{array}$ & $\begin{array}{l}0.0867 \\
(0.0329)\end{array}$ & $\begin{array}{c}0.203 \\
(0.0490)\end{array}$ & $\begin{array}{c}0.141 \\
(0.0323)\end{array}$ \\
\hline non-farm wage & $\begin{array}{l}0.0986 \\
(0.0299)\end{array}$ & $\begin{array}{c}0.118 \\
(0.0179)\end{array}$ & $\begin{array}{l}0.0422 \\
(0.0286)\end{array}$ & $\begin{array}{l}0.0631 \\
(0.0173)\end{array}$ & $\begin{array}{c}0.153 \\
(0.0302)\end{array}$ & $\begin{array}{c}0.131 \\
(0.0179)\end{array}$ \\
\hline non-farm SE & $\begin{array}{c}0.0022 \\
(0.0366)\end{array}$ & $\begin{array}{l}0.0427 \\
(0.0253)\end{array}$ & $\begin{array}{r}-0.0241 \\
(0.0327)\end{array}$ & $\begin{array}{l}0.0543 \\
(0.0238)\end{array}$ & $\begin{array}{l}0.0304 \\
(0.0355)\end{array}$ & $\begin{array}{l}0.0772 \\
(0.0250)\end{array}$ \\
\hline$R^{2}$ & 0.095 & 0.110 & 0.064 & 0.066 & 0.085 & 0.104 \\
\hline observations & 2054 & 4087 & 2065 & 4088 & 2054 & 4087 \\
\hline
\end{tabular}

Notes: Coefficient estimates from the linear probability model, equation (1). See text for details on variables. Standard errors in parentheses. 
of the $1920 \mathrm{~s}$ and 1930s. For the $1920 \mathrm{~s}$ regression, $\pi_{i}$ obviously indicates whether individual $i$ moved between 1920 and 1930, and $X_{i}$ denotes individual-level characteristics in 1920. Since information on education is not available for the 1920s sample, we omit these variables from the regression specification.

Comparing columns 1 and 2 of Table 6 reveals a large degree of similarity across decades in the estimated coefficients on inter-county migration. ${ }^{22}$ A couple of differences are worth noting. First, living in one's birth state has no effect on migration probability in the 1930s. By contrast, birth state has a strong negative effect in the 1920s, just as it does for the rest of the U.S. in the 1930s. Hence, the fact that individuals viewed the cost of leaving one's birth state as negligible, relative to the benefit of moving, is unique to the Dust Bowl experience. Second, wage workers (either farm or non-farm) from the Dust Bowl region in the 1920s have a higher probability of moving relative to the self-employed. This pattern is similar to the rest of the U.S. in the 1930s (though the effects of occupation are not statistically significant in columns 1 and 3 of Table 5). Hence, the fact that farmers were the least likely to move is also unique to the Dust Bowl, and not a feature of residents of the region in a broader sense.

For brevity, we do not discuss the remaining results in Table 6 in detail. In columns 3 and 4, we present the case of inter-state migration. Again, the result that Dust Bowl farmers were least likely to move across state lines is not shared by residents of the region in the 1920s. As documented in Subsection 3.2, a greater fraction of inter-county migration represented exodus from the region during the Dust Bowl compared to the 1920s. In columns 5 and 6, we present estimates of equation (1) where the dependent variable is an indicator for leaving the set of twenty Dust Bowl counties. The results are largely unchanged relative to those for inter-county migration presented in columns 1 and 2 .

As discussed in Subsection 3.3, the majority of Dust Bowl migrants moved prior to 1935. We also investigate whether early-decade and late-decade migrants differ systematically in terms of observable characteristics. Briefly, we find such evidence; detailed results are presented and discussed in Appendix D. Finally, we analyze the determinants of moving to California during the 1930s, and how these differed for Dust Bowl migrants compared to others. Perhaps most interestingly, those working in agriculture were no more likely to move to California than others. This contrasts with the popular notion that those who went west were displaced farmers and farm laborers seeking agricultural work in California's produce fields and orchards. Again, we refer the reader to Appendix D for details.

\footnotetext{
${ }^{22}$ Though not directly relevant for the analysis of the 1920 s versus the 1930 s, consider the comparison of columns 2 and 4 in Table 6 with column 2 in Tables 5 and 14, respectively. This demonstrates, again, the robustness of our regression results on Dust Bowl migration, this time to the exclusion of the education measure: the coefficient estimates on the remaining variables are substantively unchanged.
} 


\subsection{Decomposing Dust Bowl Differences}

Section 3 documents large differences in inter-county and inter-state migration rates between the Dust Bowl and elsewhere in the U.S. In this subsection, we use the results from Subsection 4.1 to decompose the differences in migration rates into explained and unexplained effects.

Let $\bar{\pi}^{1}$ denote the migration rate observed within the sample of heads in the Dust Bowl counties, and $\bar{\pi}^{0}$ be the migration rate observed within the sample of heads elsewhere in the U.S. Clearly, the migration rates are related to the individual-level migration indicators, $\pi_{i}$, of equation (1) via $\bar{\pi}^{J}=(1 / N) \sum_{i=1}^{N} \pi_{i}^{J}$, for $J=\{0,1\}$.

Following Oaxaca (1973) and Blinder (1973), we decompose the difference in migration rates across Dust Bowl and non-Dust Bowl regions as:

$$
\begin{aligned}
\bar{\pi}^{1}-\bar{\pi}^{0} & =\bar{X}^{1} \hat{\beta}^{1}-\bar{X}^{0} \hat{\beta}^{0} \\
& =\left(\bar{X}^{1}-\bar{X}^{0}\right) \hat{\beta}^{0}+\bar{X}^{1}\left(\hat{\beta}^{1}-\hat{\beta}^{0}\right) .
\end{aligned}
$$

Here, $\bar{X}^{J}=(1 / N) \sum_{i=1}^{N} X_{i}^{J}$ and $\hat{\beta}^{J}$ is the estimated coefficient vector from equation (1), for $J=\{0,1\}$.

The Oaxaca-Blinder (hereafter OB) decomposition states that the difference in migration rates can be decomposed into two parts. The first, given by the first term in equation (2), is the component attributable to mean differences in covariates, $\left(\bar{X}^{1}-\bar{X}^{0}\right)$; these explained effects are the ones predicted by differences in the composition of individual-level characteristics across Dust Bowl and non-Dust Bowl regions. The second part is the component attributable to differences

in the estimated coefficients, $\left(\hat{\beta}^{1}-\hat{\beta}^{0}\right)$. These are effects that are unexplained by covariates, driven by differences in the propensity to move for individuals of particular characteristics.

Table 7 presents the results from the OB decomposition. For the sake of space and exposition, the detailed decomposition effects of certain covariates have been grouped together. The effect of the age dummies (relative to the excluded age) have been grouped together under "age." The same has been done for the dummies for "schooling" and "occupation." Finally, the dummy variables for family head, marital status, and having young children have been grouped together under "family structure."

The first column considers the difference in the inter-county migration rate between the Dust Bowl and all non-Dust Bowl counties for the benchmark specification of the linear probability model, equation (1), as presented in the leftmost columns of Table 5. The first row indicates large differences in mobility: the inter-county migration rate was 22.3 percentage points higher in the Dust Bowl. The next row indicates that relatively little of this difference-specifically, $(0.0420 \div 0.223)=18.8 \%$ - is explained by differences in the composition of individual-level characteristics. Essentially all of the explained effect is due to the fact that a smaller fraction of heads in the Dust Bowl were residing in their birth state in 1930. According to the coefficient 
Table 7: Inter-County Migration: Oaxaca-Blinder Decomposition

\begin{tabular}{|c|c|c|c|c|}
\hline & \multicolumn{2}{|c|}{ Benchmark } & \multicolumn{2}{|c|}{ Extended } \\
\hline & $\begin{array}{c}\text { Dust Bowl vs } \\
\text { Non-Dust Bowl }\end{array}$ & $\begin{array}{l}\text { Dust Bowl vs } \\
\text { Rural Non-DB }\end{array}$ & $\begin{array}{l}\text { Dust Bowl vs } \\
\text { Non-DB }\end{array}$ & $\begin{array}{l}\text { Dust Bowl vs } \\
\text { Rural Non-DB }\end{array}$ \\
\hline Difference: $\bar{\pi}^{1}-\bar{\pi}^{0}$ & $\begin{array}{c}0.223 \\
(0.0111)\end{array}$ & $\begin{array}{c}0.229 \\
(0.0139)\end{array}$ & $\begin{array}{c}0.214 \\
(0.0116)\end{array}$ & $\begin{array}{c}0.222 \\
(0.0143)\end{array}$ \\
\hline Explained & $\begin{array}{l}0.0420 \\
(0.0091)\end{array}$ & $\begin{array}{l}0.0568 \\
(0.0120)\end{array}$ & $\begin{array}{l}0.0481 \\
(0.0102)\end{array}$ & $\begin{array}{l}0.0630 \\
(0.0134)\end{array}$ \\
\hline age & $\begin{array}{l}0.0037 \\
(0.0017)\end{array}$ & $\begin{array}{l}0.0025 \\
(0.0023)\end{array}$ & $\begin{array}{l}0.0028 \\
(0.0016)\end{array}$ & $\begin{array}{l}0.0015 \\
(0.0021)\end{array}$ \\
\hline schooling & $\begin{array}{r}-0.0028 \\
(0.0010)\end{array}$ & $\begin{array}{l}0.0011 \\
(0.0016)\end{array}$ & $\begin{array}{r}-0.0027 \\
(0.0010)\end{array}$ & $\begin{array}{l}0.0018 \\
(0.0017)\end{array}$ \\
\hline occupation & $\begin{array}{l}0.0019 \\
(0.0057)\end{array}$ & $\begin{array}{r}-0.0017 \\
(0.0022)\end{array}$ & $\begin{array}{r}-0.0015 \\
(0.0063)\end{array}$ & $\begin{array}{r}-0.0018 \\
(0.0027)\end{array}$ \\
\hline family structure & $\begin{array}{l}0.0003 \\
(0.0026)\end{array}$ & $\begin{array}{l}0.0038 \\
(0.0029)\end{array}$ & $\begin{array}{l}0.0002 \\
(0.0025)\end{array}$ & $\begin{array}{l}0.0039 \\
(0.0029)\end{array}$ \\
\hline in birthstate & $\begin{array}{l}0.0359 \\
(0.0056)\end{array}$ & $\begin{array}{l}0.0414 \\
(0.0104)\end{array}$ & $\begin{array}{l}0.0385 \\
(0.0058)\end{array}$ & $\begin{array}{l}0.0470 \\
(0.0109)\end{array}$ \\
\hline home owned & $\begin{array}{l}0.0030 \\
(0.0015)\end{array}$ & $\begin{array}{l}0.0098 \\
(0.0026)\end{array}$ & $\begin{array}{l}0.0024 \\
(0.0015)\end{array}$ & $\begin{array}{c}0.0092 \\
(0.0027)\end{array}$ \\
\hline additional & & & $\begin{array}{l}0.0084 \\
(0.0046)\end{array}$ & $\begin{array}{l}0.0014 \\
(0.0054)\end{array}$ \\
\hline Unexplained & $\begin{array}{c}0.181 \\
(0.0136)\end{array}$ & $\begin{array}{c}0.173 \\
(0.0169)\end{array}$ & $\begin{array}{c}0.166 \\
(0.0146)\end{array}$ & $\begin{array}{c}0.159 \\
(0.0182)\end{array}$ \\
\hline constant & $\begin{array}{r}-0.0348 \\
(0.0549)\end{array}$ & $\begin{array}{l}0.0093 \\
(0.0718)\end{array}$ & $\begin{array}{r}-0.0678 \\
(0.0586)\end{array}$ & $\begin{array}{r}-0.0306 \\
(0.0762)\end{array}$ \\
\hline age & $\begin{array}{c}-0.0004 \\
(0.0181)\end{array}$ & $\begin{array}{r}-0.0166 \\
(0.0218)\end{array}$ & $\begin{array}{l}0.0058 \\
(0.0185)\end{array}$ & $\begin{array}{r}-0.0089 \\
(0.0222)\end{array}$ \\
\hline schooling & $\begin{array}{r}-0.0035 \\
(0.0174)\end{array}$ & $\begin{array}{r}-0.0151 \\
(0.0209)\end{array}$ & $\begin{array}{r}-0.0085 \\
(0.0183)\end{array}$ & $\begin{array}{r}-0.0176 \\
(0.0220)\end{array}$ \\
\hline occupation & $\begin{array}{l}0.0487 \\
(0.0125)\end{array}$ & $\begin{array}{l}0.0441 \\
(0.0139)\end{array}$ & $\begin{array}{l}0.0443 \\
(0.0126)\end{array}$ & $\begin{array}{l}0.0450 \\
(0.0139)\end{array}$ \\
\hline family structure & $\begin{array}{c}0.186 \\
(0.0418)\end{array}$ & $\begin{array}{c}0.156 \\
(0.0585)\end{array}$ & $\begin{array}{c}0.205 \\
(0.0442)\end{array}$ & $\begin{array}{c}0.183 \\
(0.0609)\end{array}$ \\
\hline in birthstate & $\begin{array}{l}0.0224 \\
(0.0055)\end{array}$ & $\begin{array}{l}0.0212 \\
(0.0068)\end{array}$ & $\begin{array}{l}0.0235 \\
(0.0056)\end{array}$ & $\begin{array}{l}0.0235 \\
(0.0069)\end{array}$ \\
\hline home owned & $\begin{array}{r}-0.0376 \\
(0.0106)\end{array}$ & $\begin{array}{r}-0.0264 \\
(0.0132)\end{array}$ & $\begin{array}{r}-0.0326 \\
(0.0114)\end{array}$ & $\begin{array}{r}-0.0193 \\
(0.0140)\end{array}$ \\
\hline additional & & & $\begin{array}{c}-0.0034 \\
(0.0125)\end{array}$ & $\begin{array}{r}-0.0166 \\
(0.0156)\end{array}$ \\
\hline observations & 8146 & 5913 & 7558 & 5404 \\
\hline
\end{tabular}

Notes: Estimates of Oaxaca-Blinder decomposition, equation (2). See text for details on variables. Standard errors in parentheses. 
estimates for the non-Dust Bowl reference group, this predicts higher migration.

Hence, the preponderance of the difference in migration rates across Dust Bowl counties and elsewhere is due to differences in the propensities for migration. Of the 22.3 percentage point difference in the inter-county migration rate, $81.2 \%$ is due to the unexplained effect.

In terms of the detailed decomposition, the most important difference is due to the group of covariates summarizing family structure. Differences in the propensity of family heads, the married, and those with young children to move collectively predict 18.6 percentage points higher migration from the Dust Bowl than elsewhere. Recalling the results of Table 5, while these characteristics were associated with a lower likelihood of moving for those outside the Dust Bowl, they had either no effect or substantially muted effects on migration within the Dust Bowl.

Occupational differences in migration propensities are also important in accounting for observed migration differences. As evidenced in Table 5, the likelihood of migration was much higher for all occupation groups - relative to farmers - in the Dust Bowl than they were elsewhere. Finally, the behavioral differences of Dust Bowlers residing in their state of birth contribute to the difference in migration rates. While those in their birth state were much less likely to move in the non-Dust Bowl sample, this effect was essentially nonexistent in the Dust Bowl sample. As discussed in Subsection 4.1, these occupational and birth state effects are unique to the Dust Bowl, not shared by either the non-Dust Bowl or the 1920s regional samples. As such, the differences accounted for by these factors may reasonably be attributed to the environmental and economic consequences of the Dust Bowl itself.

The second column of Table 7 decomposes the difference in migration rate between the Dust Bowl and rural non-Dust Bowl counties. Given the similarity in regression results for the "rural" and "total" samples for those outside of the Dust Bowl in Subsection 4.1, it is not surprising that the $\mathrm{OB}$ results are also very similar here. Migration rates were higher in the Dust Bowl relative to other rural areas because of higher propensities to move.

The last two columns consider robustness of the OB exercise; this is done by extending the baseline migration model to include the additional regressors of radio set ownership and being born in a different state than one's parents. The detailed decomposition effects of these variables are grouped together under the label "additional." Again, the large differences in migration rates are driven by factors unexplained by differences in covariates across Dust Bowl and non-Dust Bowl regions.

As an additional robustness check, Appendix C presents the analogous results of the Fairlie (1999) decomposition using the Probit specification. Not surprisingly, the results are essentially identical to those from the Oaxaca-Blinder decomposition in Table 7. Table 16 in Appendix C repeats the OB decomposition analysis, this time examining inter-state migration. For brevity, we do not discuss the results in detail. The primary findings are similar to the case of inter- 
county migration. Explained factors account for little of the elevated migration rates in the Dust Bowl; higher inter-state migration was due primarily to a greater propensity to move.

Finally, we have also conducted the OB decomposition for mobility rates between the 1920s and 1930s for residents of the Dust Bowl region. For brevity, we do not display these results and make them available upon request. To briefly summarize, Table 1 indicates that the intercounty migration rate was about 4 percentage points higher in the 1930s compared to the previous decade. Essentially all of this difference is due to compositional differences, specifically, the lower homeownership rate and larger fraction of non-farm wage workers in the 1930s (both factors correlate with greater mobility; see Table 6).

\section{Economic Effect of Migration}

The nature of our linked data is well suited to assessing the impact of migration on individuals' economic outcomes during the 1930s decade. Because we observe location and occupation in both 1930 and 1940, it is straightforward to estimate the effect of the decision to leave or remain in the Dust Bowl region on one's occupational earnings. We estimate this effect in two ways. We first consider a reduced form analysis of the association between migration and earnings via OLS. We also study a structural treatment effects model to identify the causal effect of migration on earnings.

Both results are of interest, for slightly different reasons. The OLS estimate reveals the correlation between migration choice and occupational earnings at the end of the decade, answering the historical question of what happened to the Dust Bowl migrants relative to those who chose to remain. This is a fundamental question with regard to the Dust Bowl, and one that has not been addressed systematically before. The structural estimate of the treatment effect informs us of the causal impact of moving. This is of economic interest in understanding how this mass

migration episode compares to other notable historical episodes and adds to our knowledge of how individuals optimize over location in an attempt to mitigate the impact of economic shocks.

\subsection{What Happened to the Migrants?}

To estimate the association between the migration decision and subsequent economic outcome for the individual, we estimate via OLS a simple, reduced-form specification:

$$
y_{i, 1940}=\tau \pi_{i}+\alpha y_{i, 1930}+X_{i} \beta+v_{i}
$$

Here, $y_{i}$ is an economic outcome variable (that we discuss shortly) for individual $i$ in 1930 and $1940, \pi_{i}$ takes on the value of 1 if the individual leaves the Dust Bowl region and 0 otherwise, 
Table 8: Dust Bowl Migration and Earnings: Reduced-Form Results

\begin{tabular}{lcccccc}
\hline \hline & \multicolumn{2}{c}{ Whole Sample } & \multicolumn{2}{c}{ Farmers } & \multicolumn{2}{c}{ Non-Farmers } \\
& Version 1 & Version 2 & Version 1 & Version 2 & Version 1 & Version 2 \\
\hline left Dust Bowl & 0.0351 & 0.0367 & 0.0949 & 0.0882 & -0.0560 & -0.0530 \\
& $(0.0140)$ & $(0.0141)$ & $(0.0188)$ & $(0.0191)$ & $(0.0207)$ & $(0.0209)$ \\
1930 earnings & 0.4950 & 0.4893 & $\mathrm{n} / \mathrm{a}$ & $\mathrm{n} / \mathrm{a}$ & 0.3417 & 0.3420 \\
& $(0.0168)$ & $(0.0170)$ & & & $(0.0235)$ & $(0.0235)$ \\
schooling & & & & & & \\
primary grad & 0.0302 & 0.0283 & 0.0350 & 0.0360 & 0.0260 & 0.0259 \\
& $(0.0158)$ & $(0.0158)$ & $(0.0176)$ & $(0.0176)$ & $(0.0281)$ & $(0.0279)$ \\
high school & 0.0869 & 0.0872 & 0.0555 & 0.0570 & 0.1163 & 0.1160 \\
& $(0.0180)$ & $(0.0180)$ & $(0.0222)$ & $(0.0222)$ & $(0.0281)$ & $(0.0281)$ \\
college & 0.2175 & 0.2210 & 0.1699 & 0.1702 & 0.2502 & 0.2549 \\
& $(0.0265)$ & $(0.0264)$ & $(0.0437)$ & $(0.0435)$ & $(0.0351)$ & $0.0351)$ \\
state fixed effects & $\mathrm{x}$ & & $\mathrm{x}$ & & $\mathrm{x}$ & \\
county fixed effects & & $\mathrm{x}$ & & $\mathrm{x}$ & & $\mathrm{x}$ \\
$R^{2}$ & 0.315 & 0.321 & 0.057 & 0.071 & 0.233 & 0.250 \\
observations & 3531 & 3531 & 1763 & 1763 & 1768 & 1768 \\
\hline \hline
\end{tabular}

Notes: Selected coefficient estimates from OLS model, equation (3). See text for details on all included variables. Standard errors in parentheses.

and $X_{i}$ is a vector of controls. ${ }^{23}$ Because the choice of whether to remain in the Dust Bowl region or leave is endogenous, $\tau$ is simply how migrants' earnings in 1940 differed from observationally similar non-migrants ("persisters," hereafter).

Unfortunately, the 1930 census contains no information on income or earnings, and the 1940 census includes income only for wage and salary earners (earnings for employers and the self-employed, including farmers, are not recorded). Both censuses do contain information on occupation. Therefore, our primary economic outcome variable is log earnings imputed on the basis of occupation. ${ }^{24}$ This allows for the measure of median earnings differences across occupations, but not differences within occupation. We also generate results using the direct income measure from the 1940 census, but because of the large number of selected individuals for whom this information is missing, we consider this for robustness purposes only.

The results are displayed in Table 8. Estimating equation (3) on all individuals in our sample

\footnotetext{
${ }^{23}$ Note that the definition of $\pi_{i}$ differs from the bulk of the previous analysis, where it was typically an indicator of inter-county or inter-state migration. In the context of the outcome effect of migration, leaving the Dust Bowl is the more natural measure. Not surprisingly, given that approximately $90 \%$ of inter-county migrants left the Dust Bowl (see Table 2) region, the results are not sensitive to this choice. Finally, $X_{i}$ includes age, education, the set of "family structure" variables, homeownership, living in birthstate, and a state-level dummy variable.

${ }^{24}$ This is the "OCCSCORE" variable from IPUMS, generated by crosswalking the 1930 occupations to 1950 occupation codes, then assigning observations the median income level for workers in each occupation in 1950. For more on the usage of this occupational earnings measure in similar settings, see Abramitzky et al. (2012) and Collins and Wanamaker (2014).
} 
indicates a statistically significant, but economically small increase in occupational earnings for migrants. This is presented in the first column. Those who left the Dust Bowl experienced occupational changes that translated to a 3.5 percent increase in earnings on average. This result, however, masks important differences between the roughly half of our sample who were farmers in 1930 and the half who were not. This is shown in columns 3 and 5. Conditional on being a farmer in 1930, migrants had 1940 occupational earnings on average 9.5 percent greater than those who stayed in the region; this is significant at the $1 \%$ level. By contrast, non-farmer migrants experienced a 5.6 percent decline in earnings relative to persisters.

Columns 2, 4, and 6 of Table 8 repeats the analysis, replacing the state fixed effect with a county fixed effect in the set of regressors. The results are largely unchanged. Finally, we have conducted the same analysis for the subsample of wage and salary earners in 1940 with reported income. We find that the same pattern emerges: small gains to migrants in the aggregate, masking large gains for farmers and moderate losses for non-farmers. ${ }^{25}$

To shed light on these results, Table 9 displays transition matrices across broad occupational groups for migrants and persisters. Occupations are grouped based on their earnings. Farmers in 1930 who left the Dust Bowl were more likely than persisters to experience downward occupational moves, becoming laborers in 1940 (21.6 versus 8.6 percent). However, this tendency for greater downward mobility was more than offset by their greater likelihood of experiencing upward moves toward semi-skilled or high-skilled occupations (39.0 percent for migrants versus 19.0 percent for persisters). The negative migration effect for non-farmers is driven primarily by the greater tendency of high-skilled migrants to transition into semi-skilled occupations relative to persisters (who were more likely to remain in a high-skill occupation). ${ }^{26}$

Clearly, contrary to long-standing popular perception, the typical Dust Bowl migrant was not destined for economic hardship and loss. Migrant farmers - far from ending up as marginalized, poorly paid agricultural laborers - enjoyed better occupational outcomes than did those who persisted. Also, the most typical downward occupational move associated with migration was a greater tendency for high-skilled migrants to transition to semi-skilled occupations, a move that, while associated with a loss in earnings on average, was not associated with falling into poverty. Two caveats apply. First, since we only observe individuals in 1930 and 1940, we cannot rule out the possibility that migrants experienced significant hardship between the time of migration and 1940. We can only rule out the prevalence of negative outcomes that persisted until 1940. Second, because we observe only occupation and impute earnings, it is possible that some individuals who made upward occupational moves earned less in 1940 than in 1930 (and, of course, vice versa). The potential error associated with using imputed rather than

\footnotetext{
${ }^{25}$ Given the highly selected nature of this subsample, and for the sake of brevity, we do not present them here and make them available upon request.

${ }^{26}$ This more than offsets the effect of greater tendency among migrant laborers to move up the occupational ladder, relative to their counterparts who stayed.
} 
Table 9: Occupational Transition Matrices: Migrants vs Persisters

\begin{tabular}{|c|c|c|c|c|c|}
\hline \multicolumn{6}{|c|}{ Dust Bowl Migrants } \\
\hline \multirow[b]{2}{*}{ Occupation Group, 1940} & \multicolumn{5}{|c|}{ Occupation Group, 1930} \\
\hline & High-skilled & Semi-skilled & Farmer & Laborer & obs \\
\hline High-skilled & 44.0 & 25.4 & 17.8 & 18.6 & 423 \\
\hline Semi-skilled & 39.2 & 55.5 & 21.3 & 32.9 & 650 \\
\hline Farmer & 8.1 & 10.6 & 39.4 & 18.3 & 424 \\
\hline Laborer & 8.6 & 8.5 & 21.6 & 30.3 & 334 \\
\hline observations & 209 & 519 & 710 & 393 & \\
\hline \multicolumn{6}{|c|}{ Dust Bowl Persisters } \\
\hline \multicolumn{6}{|c|}{ Occupation Group, 1930} \\
\hline Occupation Group, 1940 & High-skilled & Semi-skilled & Farmer & Laborer & obs \\
\hline High-skilled & 61.3 & 24.9 & 10.6 & 19.2 & 443 \\
\hline Semi-skilled & 24.6 & 58.4 & 8.4 & 25.0 & 488 \\
\hline Farmer & 10.6 & 10.1 & 72.4 & 22.3 & 1032 \\
\hline Laborer & 3.5 & 6.7 & 8.6 & 33.5 & 212 \\
\hline observations & 256 & 466 & 1265 & 188 & \\
\hline
\end{tabular}

Notes: Values in rows indicate the probability that individuals from one occupation group in 1930 (arranged by column) transits to each occupation group in 1940. High-skilled = manager, official, proprietor, etc.; semi-skilled = carpenter, mechanic, salesman, etc.; laborer = general laborer and farm laborer. Detailed information on occupation groups available from authors upon request. 
observed earnings could be more acute for farmers, for whom there was large variance in earnings nationally. However, the likelihood that we are significantly understating earnings losses of migrants who transitioned out of farming is mitigated in this specific case by the fact that high-earning, large landholding farms were uncommon in the Dust Bowl region in the 1930s.

\subsection{Selection and Treatment Effect of Migration}

While equation (3) is a straightforward means of assessing the economic outcomes of Dust Bowl migration, it is not appropriate for assessing the causal treatment effect of the migration, as individuals self-selected as migrants or persisters. Failing to account for possible migrant selectivity could result in $\tau$ being a biased estimate of the treatment effect. Theories of migration choice allow for either positive or negative selection, so the nature of selection in a particular case is an empirical question.

Following McKenzie et al. (2010) and Collins and Wanamaker (2014), a simple measure of migrant selectivity can be obtained by estimating the relationship between earnings in 1930 and the subsequent migration decision:

$$
\pi_{i}=\theta y_{i, 1930}+X_{i} \beta+\epsilon_{i}
$$

When the individual-level controls $X_{i}$ are omitted from equation (4), $\theta$ is a simple measure of migrant selectivity; with $X_{i}$ included, $\theta$ measures "selection on unobservables." In either case, $\theta>0$ indicates that migrants were positively selected, and $\theta<0$ that they were negatively selected.

For brevity, we summarize here and make details of our results available upon request. Estimating equation (4), there is evidence of mild positive selection on unobservables $(\theta=$ 0.0482 , s.e. $=0.0182$ ); this is balanced by mild negative selection on certain observables (such as family headship and home ownership). As a result, estimating equation (4) without controlling for $X_{i}$, we find no appreciable evidence of selection among the Dust Bowl migrants $(\theta=0.0198$, s.e. $=0.0178)$.

It is instructive to put this finding in context with other migration episodes. One straightforward comparison is with out-migration from this same region in the 1920s (a period when gross migration rates were high, as documented in Section 3). Estimating equation (4) on the 1920s sample without controlling for $X_{i}$, we find stronger evidence of positive selection: migrants' earnings were 5.7 log points greater than non-migrants, and this difference is statistically significant at the $5 \%$ level. ${ }^{27}$ Migrant selectivity during the Dust Bowl was also small relative to two other important U.S. migration episodes. African-American participants in the Great Migration of the early twentieth century had pre-migration earnings 10 to 15 log points higher than

\footnotetext{
${ }^{27}$ Controlling for $X_{i}$, we also find positive selection on unobservables. However, it should be noted that data on educational attainment, an important determinant of earnings, is not available for the 1920s sample.
} 
non-migrants (see Collins and Wanamaker (2014)). And while differing methodologies prevent direct comparison, Abramitzky et al. (2012) find strong evidence of negative selection among urban Norwegian migrants to the U.S. during the age of mass migration in the nineteenth and early twentieth centuries.

A complementary approach to accounting for possible migrant selectivity is to explicitly model the migration choice along with the determination of earnings in 1940. We consider a treatment effects model that identifies the causal effect of migration on earnings. The earnings equation is simply (3) from above. However, $\pi_{i}$ is now modeled as an observed binary decision to leave or remain in the Dust Bowl region, driven by an unobserved latent variable:

$$
\pi_{i}^{*}=\gamma_{1} y_{i, 1930}+Z_{i} \gamma_{2}+\epsilon_{i}
$$

that represents the net benefit of migration. Consequently:

$$
\pi_{i}=\left\{\begin{array}{ll}
1 & \text { if } \pi_{i}^{*}>0 \\
0 & \text { otherwise }
\end{array},\right.
$$

where $v$ and $\epsilon$ are assumed to be distributed bivariate normal with mean zero. The modelequations (3), (5), and (6) - is estimated via maximum likelihood. ${ }^{28}$

If $Z_{i}$ contains at least one variable that is excluded from $X_{i}$, then $\tau$ is identified without reliance on the precise functional form of the model. In this case, a feature of the 1930 census provides a plausible exclusion restriction. Respondents were asked whether they owned a "radio set," the only time the census has asked about a consumer good in the main questionnaire. Households with radios would likely have been more informed than those without, particularly with respect to economic conditions beyond the local area. This information would have been pertinent to migration choice. But given the nature of information dissemination, even households without radios would have been informed if they were in contact with those who did own radios. To capture the effect of information acquired via radio (both directly and by word-ofmouth), we use the share of households in the county with radio sets, and include this measure in $Z_{i}$ but not in $X_{i}$. Using county-level radio penetration rather than individual-level radio ownership has the added benefit of avoiding the possible correlation between ownership and household wealth, which would argue against exclusion from $X_{i}{ }^{29}$

One potential weakness of this method is that, even at the county level, prevalence of radio ownership in 1930 could be correlated with 1940 earnings, perhaps being related to local economic development in a way that mattered to individuals' 1940 occupation. To account for this, we include in $X_{i}$ and $Z_{i}$ several county-level controls for economic development and/or job opportunity alongside our individual-level controls. The county-level controls are per capita

\footnotetext{
${ }^{28}$ See Maddala (1983), pp. 117-122, for discussion and derivation of the likelihood function.

${ }^{29}$ For a similar use of 1930 county-level radio penetration as a measure of information, see Ziebarth (2013).
} 
Table 10: Dust Bowl Migration and Earnings: Treatment Effects Results

\begin{tabular}{|c|c|c|c|c|c|c|}
\hline & \multicolumn{2}{|c|}{ Whole Sample } & \multicolumn{2}{|c|}{ Farmers } & \multicolumn{2}{|c|}{ Non-Farmers } \\
\hline & $\begin{array}{l}\text { Earnings } \\
\text { equation }\end{array}$ & $\begin{array}{c}\text { Migration } \\
\text { equation }\end{array}$ & $\begin{array}{l}\text { Earnings } \\
\text { Equation }\end{array}$ & $\begin{array}{c}\text { Migration } \\
\text { Equation }\end{array}$ & $\begin{array}{l}\text { Earnings } \\
\text { Equation }\end{array}$ & $\begin{array}{c}\text { Migration } \\
\text { Equation }\end{array}$ \\
\hline left Dust Bowl & $\begin{array}{l}-0.0362 \\
(0.0223)\end{array}$ & & $\begin{array}{l}0.0942 \\
(0.0251)\end{array}$ & & $\begin{array}{l}-0.3383 \\
(0.1102)\end{array}$ & \\
\hline radio penetration & & $\begin{array}{l}-0.0305 \\
(0.0104)\end{array}$ & & $\begin{array}{r}-0.0559 \\
(0.0087)\end{array}$ & & $\begin{array}{l}-0.0222 \\
(0.0153)\end{array}$ \\
\hline 1930 earnings & $\begin{array}{l}0.4941 \\
(0.0226)\end{array}$ & $\begin{array}{l}0.1438 \\
(0.0571)\end{array}$ & $\mathrm{n} / \mathrm{a}$ & $\mathrm{n} / \mathrm{a}$ & $\begin{array}{l}0.3195 \\
(0.0238)\end{array}$ & $\begin{array}{c}-0.1974 \\
(0.0650)\end{array}$ \\
\hline $\begin{array}{l}\text { age } \\
16-25 \text { yrs }\end{array}$ & $\begin{array}{l}0.0741 \\
(0.0275)\end{array}$ & $\begin{array}{l}0.4613 \\
(0.0904)\end{array}$ & $\begin{array}{l}0.0360 \\
(0.0329)\end{array}$ & $\begin{array}{l}0.3498 \\
(0.1321)\end{array}$ & $\begin{array}{l}0.0451 \\
(0.0433)\end{array}$ & $\begin{array}{l}0.4078 \\
(0.1435)\end{array}$ \\
\hline $26-35$ yrs & $\begin{array}{l}0.0873 \\
(0.0183)\end{array}$ & $\begin{array}{l}0.1360 \\
(0.0638)\end{array}$ & $\begin{array}{l}0.0953 \\
(0.0253)\end{array}$ & $\begin{array}{l}0.0857 \\
(0.0840)\end{array}$ & $\begin{array}{l}0.0526 \\
(0.0208)\end{array}$ & $\begin{array}{l}0.1313 \\
(0.0933)\end{array}$ \\
\hline $36-45$ yrs & $\begin{array}{l}0.0209 \\
(0.0182)\end{array}$ & $\begin{array}{l}0.0481 \\
(0.0797)\end{array}$ & $\begin{array}{l}0.0483 \\
(0.0201)\end{array}$ & $\begin{array}{r}-0.0157 \\
(0.0894)\end{array}$ & $\begin{array}{c}-0.0178 \\
(0.0294)\end{array}$ & $\begin{array}{l}0.1061 \\
(0.0980)\end{array}$ \\
\hline $\begin{array}{l}\text { schooling } \\
\text { primary grad }\end{array}$ & $\begin{array}{l}0.0321 \\
(0.0128)\end{array}$ & $\begin{array}{l}0.0807 \\
(0.0639)\end{array}$ & $\begin{array}{l}0.0357 \\
(0.0144)\end{array}$ & $\begin{array}{l}0.1302 \\
(0.1039)\end{array}$ & $\begin{array}{l}0.0299 \\
(0.0228)\end{array}$ & $\begin{array}{l}0.0477 \\
(0.0674)\end{array}$ \\
\hline high school & $\begin{array}{c}0.0852 \\
(0.0164)\end{array}$ & $\begin{array}{c}-0.0581 \\
(0.0545)\end{array}$ & $\begin{array}{l}0.0550 \\
(0.0164)\end{array}$ & $\begin{array}{c}-0.1229 \\
(0.0850)\end{array}$ & $\begin{array}{l}0.1128 \\
(0.0314)\end{array}$ & $\begin{array}{c}-0.0108 \\
(0.0825)\end{array}$ \\
\hline college & $\begin{array}{l}0.2188 \\
(0.0347)\end{array}$ & $\begin{array}{l}0.0249 \\
(0.0639)\end{array}$ & $\begin{array}{l}0.1678 \\
(0.0484)\end{array}$ & $\begin{array}{c}-0.0140 \\
(0.1905)\end{array}$ & $\begin{array}{l}0.2526 \\
(0.0378)\end{array}$ & $\begin{array}{l}0.0497 \\
(0.1110)\end{array}$ \\
\hline observations & 3531 & 3531 & 1763 & 1763 & 1768 & 1768 \\
\hline
\end{tabular}

Notes: Selected coefficient estimates from treatment effects model, equations (3), (5), and (6). See text for details on all included variables. Robust standard errors, clustered at county level, in parentheses.

measures of crop value and retail sales in 1929, the mean and standard deviation of occupational earnings in 1930, and New Deal spending on public works/relief grants and AAA benefits from 1933-39. ${ }^{30}$ The individual-level controls are the same as those in the regression analysis of equation (3) in Subsection 5.1.

Table 10 presents the results of maximum likelihood estimation of the treatment effects model. Column 2 indicates that individuals who lived in counties with greater radio ownership were significantly less likely to leave the Dust Bowl region. The coefficient estimate of -0.0293 implies that a one standard deviation increase in radio penetration led to a 12 pp reduction in out-migration probability, relative to a baseline probability of 46 percent. Column 4 indicates that this affect was stronger for farmers, for whom a one standard deviation increase decreased out-migration by 23 percentage points. ${ }^{31}$ One plausible interpretation is that those with access

\footnotetext{
${ }^{30}$ The county-level variables, including radio penetration, but excluding the mean and standard deviation of occupational earnings, are obtained from Fishback et al. (2006).

${ }^{31}$ If the migration equation is estimated via OLS, as if it were the first stage in an instrumental variables estimation of equation (3), the $F$-statistic on radio penetration is 11.7 for the whole sample, 21.3 for farmers, and
} 
to information via radio better understood that economic conditions and labor market prospects were poor not only in one's own Dust Bowl-affected county, but throughout the Great Plains and nation as a whole. To the extent that individuals perceived economic distress to be a macroeconomic phenomenon, they may have been less inclined to move to seek better opportunity elsewhere.

Turning to the treatment effect estimates, we see a pattern that is similar to the simple OLS results. Column 1 of Table 10 indicates a small effect of migration on earnings for the whole sample, in this case negative and statistically insignificant. Column 3, on the other hand, indicates a significant positive effect for those who were farmers in 1930. Leaving the Dust Bowl resulted in an approximate 9 log point increase in occupational earnings, an effect very similar to the one found in Subsection 5.1. ${ }^{32}$ This similarity between the reduced-form estimate and the structural estimate of the causal effect is consistent with negligible migrant selectivity (either positive or negative), corroborating the results from the analysis of selectivity via equation (4) above.

Perhaps this is not surprising for the Dust Bowl migration, given the environmental catastrophe. In contrast to other notable historical episodes, such as 19th and early-20th century mass European migration to the U.S. and the 20th century Great Migration of African Americans from the South to the North, Dust Bowl migrants were perhaps driven to a greater extent by necessity or desperation, relative to a more calculated weighing of costs and benefits of location choice. In this sense, migration from the Dust Bowl would have been closer to a randomly assigned treatment than is typical. Regardless, both the structural and reduced-form estimates indicate that migration from the Dust Bowl was not associated with long-lasting negative labor market effects; for farmers, the effects were positive on average.

\section{Conclusion}

This research represents the first attempt to systematically measure and analyze gross migration flows associated with the Dust Bowl of the 1930s. We construct longitudinal data from the U.S. Census records to study migration patterns and their outcomes for those most greatly affected by the economic and environmental crisis. A number of novel findings emerge.

First, migration rates were much higher in the Dust Bowl compared to everywhere else in the U.S. This excess migration is due to the fact that individual-level characteristics that were neg-

1.3 for non-farmers. With standard errors clustered at the county level, those $F$-statistics are $6.7,39.9$, and 0.7 respectively. Because of the low $F$-statistic for non-farmers, we are reluctant to draw inference from the results for that subsample.

${ }^{32}$ Note also that Table 10 indicates a negative effect for non-farmers. Relative to the OLS results, the effect is much stronger. But as discussed above, the weak association between radio penetration and migration probability makes the results for the non-farmer subsample suspect. 
atively associated with mobility elsewhere (those related to family structure and local/regional ties) were unrelated to migration probability within the Dust Bowl. Second, relative to other occupational groups, farmers in the Dust Bowl were the least likely to move; by contrast, no relationship existed between migration probability and occupation outside of the Dust Bowl. This is surprising, given the cultural notion of the migrant Dust Bowl farmer expelled from the land. Third, out-migration rates from the Dust Bowl were not much higher than they were from the same region in the 1920s. Hence, the depopulation of the Dust Bowl was due largely to a sharp drop in migrant inflows during the 1930s. Fourth, the westward exodus from the Dust Bowl to California was unexceptional; migrants from the Dust Bowl were no more likely to move to California than migrants from any other part of the country. Instead, Dust Bowl migrants made relatively local moves, tending to remain in one of the Dust Bowl affected states. Finally, there is no appreciable evidence of selection (either positive or negative) among the Dust Bowl migrants. As a result, reduced-form estimates and structural estimates of the causal effect of leaving the Dust Bowl are similar: migration was not associated with long-lasting negative earnings effects on the whole, whereas for farmers, the effects were positive. 


\section{Appendix}

\section{A Additional Tables and Figures: Sections 2 and 3}

Table 11: Summary Statistics: Matched Sample

\begin{tabular}{|c|c|c|c|c|}
\hline & $\begin{array}{c}\text { Dust Bowl } \\
1930-40\end{array}$ & $\begin{array}{c}\text { Non-Dust Bowl } \\
1930-40\end{array}$ & $\begin{array}{c}\text { Rural Non-DB } \\
1930-40\end{array}$ & $\begin{array}{c}\text { Dust Bowl } \\
1920-30\end{array}$ \\
\hline \multicolumn{5}{|l|}{ age } \\
\hline $16-25$ yrs & 0.129 & 0.110 & 0.127 & 0.103 \\
\hline $26-35$ yrs & 0.300 & 0.278 & 0.266 & 0.325 \\
\hline $36-45$ yrs & 0.283 & 0.297 & 0.284 & 0.303 \\
\hline $46-60$ yrs & 0.288 & 0.315 & 0.323 & 0.272 \\
\hline family head & 0.915 & 0.928 & 0.940 & 0.948 \\
\hline married & 0.884 & 0.907 & 0.906 & 0.904 \\
\hline \multicolumn{5}{|l|}{ no. of children } \\
\hline 0 & 0.283 & 0.301 & 0.275 & 0.239 \\
\hline $1-2$ & 0.368 & 0.411 & 0.385 & 0.355 \\
\hline $3-4$ & 0.223 & 0.188 & 0.208 & 0.250 \\
\hline $5+$ & 0.127 & 0.100 & 0.132 & 0.156 \\
\hline child under 5 & 0.369 & 0.309 & 0.349 & 0.450 \\
\hline in birthstate & 0.218 & 0.600 & 0.682 & 0.137 \\
\hline home owned & 0.468 & 0.487 & 0.526 & 0.592 \\
\hline \multicolumn{5}{|l|}{ schooling } \\
\hline less than 8 yrs & 0.273 & 0.273 & 0.334 & $\mathrm{n} / \mathrm{a}$ \\
\hline primary grad & 0.369 & 0.335 & 0.344 & $\mathrm{n} / \mathrm{a}$ \\
\hline high school & 0.264 & 0.269 & 0.242 & $\mathrm{n} / \mathrm{a}$ \\
\hline college & 0.094 & 0.124 & 0.079 & $\mathrm{n} / \mathrm{a}$ \\
\hline \multicolumn{5}{|l|}{ occupation } \\
\hline farm labor & 0.072 & 0.039 & 0.074 & 0.056 \\
\hline farmer & 0.488 & 0.195 & 0.407 & 0.665 \\
\hline non-farm wage & 0.324 & 0.625 & 0.408 & 0.183 \\
\hline non-farm SE & 0.116 & 0.141 & 0.110 & 0.095 \\
\hline own radio & 0.277 & 0.491 & 0.387 & $\mathrm{n} / \mathrm{a}$ \\
\hline diff. from parent birthstate & 0.907 & 0.552 & 0.457 & 0.957 \\
\hline observations & 4210 & 4335 & 2024 & 2090 \\
\hline
\end{tabular}

Notes: Statistics represent fractions satisfying each characteristic, for samples of individuals matched across successive decennial censuses. See text for details. 
Table 12: Summary Statistics: Random Sample

\begin{tabular}{lcc}
\hline \hline & $\begin{array}{c}\text { Dust Bowl } \\
1930-40\end{array}$ & $\begin{array}{c}\text { Non-Dust Bowl } \\
1930-40\end{array}$ \\
\hline age & & \\
16-25 yrs & 0.158 & 0.110 \\
26-35 yrs & 0.272 & 0.278 \\
36-45 yrs & 0.284 & 0.297 \\
46-60 yrs & 0.285 & 0.315 \\
family head & 0.854 & 0.857 \\
married & 0.804 & 0.826 \\
no. of children & & \\
0 & 0.373 & 0.383 \\
1-2 & 0.340 & 0.354 \\
3-4 & 0.184 & 0.169 \\
5+ & 0.104 & 0.094 \\
child under 5 & 0.324 & 0.272 \\
in birthstate & 0.185 & 0.519 \\
home owned & 0.486 & 0.549 \\
occupation & & \\
farm labor & 0.108 & 0.049 \\
farmer & 0.429 & 0.175 \\
non-farm wage & 0.343 & 0.667 \\
non-farm SE & 0.119 & 0.109 \\
own radio & 0.242 & 0.410 \\
diff. from parent birthstate & 0.917 & 260982 \\
observations & 2060 & \\
\hline \hline
\end{tabular}

Notes: Statistics represent fractions of census samples satisfying each characteristic. 
Figure 4: Heat Map of Migration Destinations: Five States
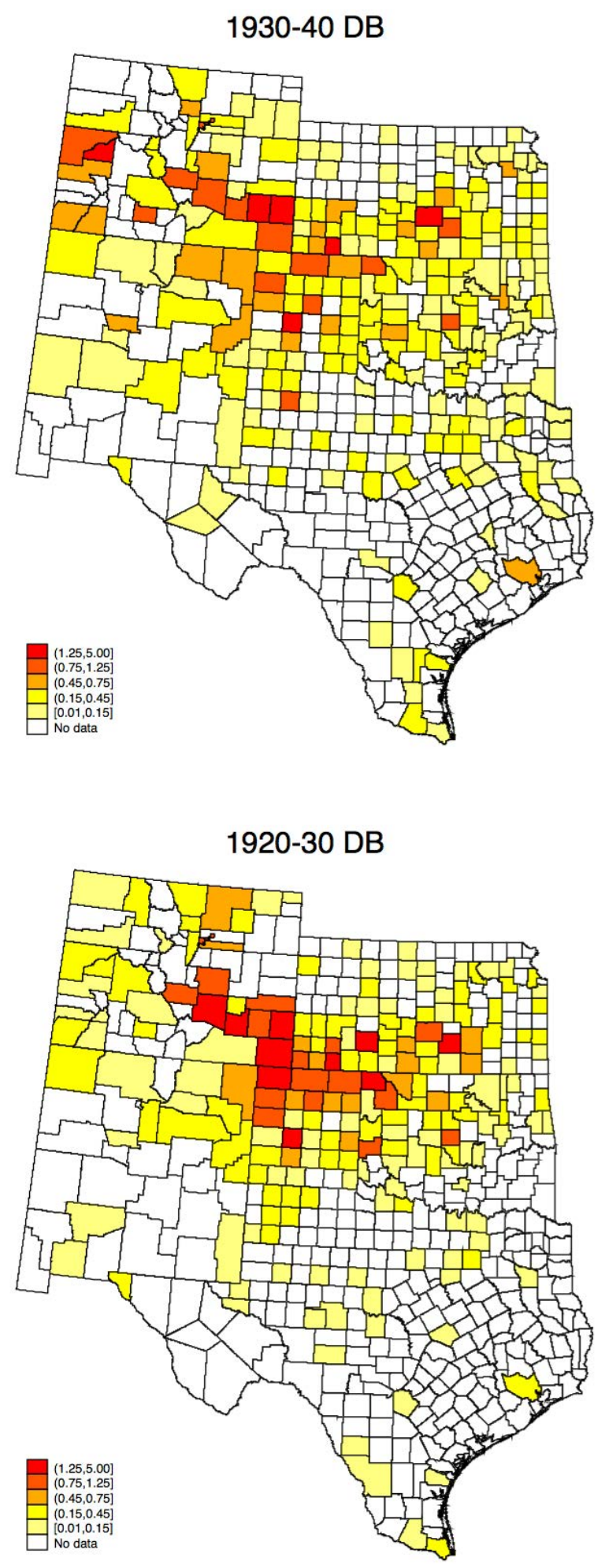

Notes: Darker (red) colors indicate locations of greater migration incidence from the Dust Bowl region, lighter (yellow) colors indicate the opposite. See text for details. 


\section{B Imputing In-Migration}

The population of the twenty Dust Bowl counties in 1920, 1930, and 1940 are available from the Census.

For the 1930s, data on the number of births and deaths are available annually, at the countylevel. These are from the U.S. Bureau of the Census, Birth, Stillbirth, and Infant Mortality Statistics for the Continental United States, the Territory of Hawaii, the Virgin Islands and Mortality Statistics for 1930-36, and Vital Statistics of the United States for 1937-39. The exception to this are the eight counties in Texas, where fertility and mortality statistics are available beginning only in 1933. As such, the data for Texas, 1930-32, are imputing using the birth and death rates from the six counties in Kansas.

Using these vital statistics data, and assuming that the out-migration rate that we have derived on heads applies to all individuals, the implied number of in-migrants to the Dust Bowl region during the 1930s was 18,694. Expressed relative to the population in 1930, this translates into an in-migration rate of $15.5 \%$. For robustness, we have also imputed the 1930-32 statistics for Texas using the birth and death rates from all of the other Dust Bowl counties (in Colorado, Kansas, and Oklahoma), and obtain very similar results. Doing so implies 18,826 in-migrants to the Dust Bowl, or an in-migration rate of $15.6 \%$.

For the 1920s, vital statistics at the county-level are available only for Kansas for the entire decade. Data for the Colorado and Oklahoma counties are available only for 1928-29. These are from Birth, Stillbirth, and Infant Mortality Statistics for the Continental United States, the Territory of Hawaii, the Virgin Islands and Mortality Statistics. No data are available for Texas. As such, the missing data are imputing using the birth and death rates from the six counties in Kansas, in the same manner as done for the 1930s.

Using these data, and assuming that the out-migration rate for heads applies to all individuals, the implied number of in-migrants to the region during the 1920s was 46,134. Expressed relative to the population in 1920 , this is in-migration rate of $47.3 \%$. For robustness, we have also imputed the missing vital statistics using the birth and death rates for the rural white population of the geographically similar states of Kansas, Nebraska, and Wyoming; again, we obtain similar results. Doing so implies 45,605 in-migrants during the 1920s, or an in-migration rate of $46.8 \%$.

\section{Additional Tables: Section 4}


Table 13: Determinants of Inter-County Migration: Probit Results

\begin{tabular}{|c|c|c|c|c|c|c|}
\hline & \multicolumn{3}{|c|}{ Benchmark } & \multicolumn{3}{|c|}{ Extended } \\
\hline & $\begin{array}{c}\text { Non- } \\
\text { Dust Bowl }\end{array}$ & $\begin{array}{l}\text { Dust } \\
\text { Bowl }\end{array}$ & $\begin{array}{c}\text { Rural } \\
\text { Non-DB }\end{array}$ & $\begin{array}{c}\text { Non- } \\
\text { Dust Bowl }\end{array}$ & $\begin{array}{l}\text { Dust } \\
\text { Bowl }\end{array}$ & $\begin{array}{c}\text { Rural } \\
\text { Non-DB }\end{array}$ \\
\hline \multicolumn{7}{|l|}{ age } \\
\hline $16-25$ yrs & $\begin{array}{c}0.188 \\
(0.0445)\end{array}$ & $\begin{array}{c}0.173 \\
(0.0308)\end{array}$ & $\begin{array}{c}0.205 \\
(0.0631)\end{array}$ & $\begin{array}{c}0.180 \\
(0.0449)\end{array}$ & $\begin{array}{c}0.179 \\
(0.0332)\end{array}$ & $\begin{array}{c}0.195 \\
(0.0640)\end{array}$ \\
\hline $26-35$ yrs & $\begin{array}{c}0.0566 \\
(0.0218)\end{array}$ & $\begin{array}{c}0.0531 \\
(0.0243)\end{array}$ & $\begin{array}{c}0.0838 \\
(0.0325)\end{array}$ & $\begin{array}{c}0.0531 \\
(0.0221)\end{array}$ & $\begin{array}{c}0.0594 \\
(0.0259)\end{array}$ & $\begin{array}{c}0.0780 \\
(0.0329)\end{array}$ \\
\hline $36-45$ yrs & $\begin{array}{c}0.0250 \\
(0.0191)\end{array}$ & $\begin{array}{c}0.0326 \\
(0.0224)\end{array}$ & $\begin{array}{c}0.0639 \\
(0.0288)\end{array}$ & $\begin{array}{c}0.0210 \\
(0.0194)\end{array}$ & $\begin{array}{c}0.0376 \\
(0.0237)\end{array}$ & $\begin{array}{c}0.0570 \\
(0.0292)\end{array}$ \\
\hline family head & $\begin{array}{c}-0.213 \\
(0.0481)\end{array}$ & $\begin{array}{c}-0.159 \\
(0.0444)\end{array}$ & $\begin{array}{c}-0.198 \\
(0.0832)\end{array}$ & $\begin{array}{c}-0.208 \\
(0.0490)\end{array}$ & $\begin{array}{c}-0.124 \\
(0.0493)\end{array}$ & $\begin{array}{c}-0.193 \\
(0.0838)\end{array}$ \\
\hline married & $\begin{array}{c}-0.110 \\
(0.0386)\end{array}$ & $\begin{array}{l}-0.0197 \\
(0.0383)\end{array}$ & $\begin{array}{l}-0.0865 \\
(0.0586)\end{array}$ & $\begin{array}{c}-0.101 \\
(0.0391)\end{array}$ & $\begin{array}{l}-0.0160 \\
(0.0403)\end{array}$ & $\begin{array}{l}-0.0905 \\
(0.0594)\end{array}$ \\
\hline young child & $\begin{array}{l}-0.0497 \\
(0.0179)\end{array}$ & $\begin{array}{c}0.0259 \\
(0.0192)\end{array}$ & $\begin{array}{l}-0.0589 \\
(0.0255)\end{array}$ & $\begin{array}{l}-0.0527 \\
(0.0181)\end{array}$ & $\begin{array}{c}0.0211 \\
(0.0204)\end{array}$ & $\begin{array}{l}-0.0568 \\
(0.0258)\end{array}$ \\
\hline in birthstate & $\begin{array}{c}-0.104 \\
(0.0157)\end{array}$ & $\begin{array}{l}-0.0013 \\
(0.0200)\end{array}$ & $\begin{array}{c}-0.100 \\
(0.0247)\end{array}$ & $\begin{array}{c}-0.109 \\
(0.0160)\end{array}$ & $\begin{array}{c}0.0032 \\
(0.0219)\end{array}$ & $\begin{array}{c}-0.110 \\
(0.0251)\end{array}$ \\
\hline $\begin{array}{l}\text { home owned } \\
\text { schooling }\end{array}$ & $\begin{array}{c}-0.138 \\
(0.0156)\end{array}$ & $\begin{array}{c}-0.212 \\
(0.0173)\end{array}$ & $\begin{array}{c}-0.162 \\
(0.0233)\end{array}$ & $\begin{array}{c}-0.133 \\
(0.0159)\end{array}$ & $\begin{array}{c}-0.196 \\
(0.0188)\end{array}$ & $\begin{array}{c}-0.161 \\
(0.0238)\end{array}$ \\
\hline primary grad & $\begin{array}{l}-0.0346 \\
(0.0192)\end{array}$ & $\begin{array}{c}0.0186 \\
(0.0212)\end{array}$ & $\begin{array}{l}-0.0228 \\
(0.0269)\end{array}$ & $\begin{array}{l}-0.0264 \\
(0.0198)\end{array}$ & $\begin{array}{c}0.0224 \\
(0.0227)\end{array}$ & $\begin{array}{l}-0.0189 \\
(0.0277)\end{array}$ \\
\hline high school & $\begin{array}{c}0.0131 \\
(0.0216)\end{array}$ & $\begin{array}{l}-0.0383 \\
(0.0239)\end{array}$ & $\begin{array}{c}0.0375 \\
(0.0322)\end{array}$ & $\begin{array}{c}0.0249 \\
(0.0224)\end{array}$ & $\begin{array}{l}-0.0363 \\
(0.0257)\end{array}$ & $\begin{array}{c}0.0434 \\
(0.0335)\end{array}$ \\
\hline college & $\begin{array}{c}0.0529 \\
(0.0277)\end{array}$ & $\begin{array}{l}-0.0420 \\
(0.0320)\end{array}$ & $\begin{array}{c}0.0630 \\
(0.0468)\end{array}$ & $\begin{array}{c}0.0675 \\
(0.0288)\end{array}$ & $\begin{array}{l}-0.0325 \\
(0.0341)\end{array}$ & $\begin{array}{c}0.0809 \\
(0.0480)\end{array}$ \\
\hline $\begin{array}{l}\text { occupation } \\
\text { farm labor }\end{array}$ & $\begin{array}{c}0.0763 \\
(0.0519)\end{array}$ & $\begin{array}{c}0.121 \\
(0.0355)\end{array}$ & $\begin{array}{c}0.0628 \\
(0.0535)\end{array}$ & $\begin{array}{c}0.0737 \\
(0.0514)\end{array}$ & $\begin{array}{c}0.117 \\
(0.0382)\end{array}$ & $\begin{array}{c}0.0598 \\
(0.0533)\end{array}$ \\
\hline non-farm wage & $\begin{array}{c}0.0070 \\
(0.0205)\end{array}$ & $\begin{array}{c}0.131 \\
(0.0193)\end{array}$ & $\begin{array}{c}0.0248 \\
(0.0254)\end{array}$ & $\begin{array}{c}0.0142 \\
(0.0212)\end{array}$ & $\begin{array}{c}0.135 \\
(0.0210)\end{array}$ & $\begin{array}{c}0.0190 \\
(0.0262)\end{array}$ \\
\hline non-farm SE & $\begin{array}{l}-0.0092 \\
(0.0271)\end{array}$ & $\begin{array}{c}0.0554 \\
(0.0277)\end{array}$ & $\begin{array}{c}-0.0074 \\
(0.0388)\end{array}$ & $\begin{array}{l}-0.0013 \\
(0.0282)\end{array}$ & $\begin{array}{c}0.0660 \\
(0.0298)\end{array}$ & $\begin{array}{c}-0.0067 \\
(0.0400)\end{array}$ \\
\hline own radio & & & & $\begin{array}{l}-0.0549 \\
(0.0163)\end{array}$ & $\begin{array}{c}-0.103 \\
(0.0203)\end{array}$ & $\begin{array}{l}-0.0213 \\
(0.0240)\end{array}$ \\
\hline parent birthstate & & & & $\begin{array}{l}-0.0169 \\
(0.0171)\end{array}$ & $\begin{array}{c}0.0035 \\
(0.0182)\end{array}$ & $\begin{array}{l}-0.0032 \\
(0.0252)\end{array}$ \\
\hline observations & 4185 & 3961 & 1952 & 4052 & 3506 & 1898 \\
\hline
\end{tabular}

Notes: Coefficient estimates from probit model. See text for details on variables. Standard errors in parentheses. 
Table 14: Determinants of Inter-State Migration: Regression Results

\begin{tabular}{|c|c|c|c|c|c|c|}
\hline & \multicolumn{3}{|c|}{ Benchmark } & \multicolumn{3}{|c|}{ Extended } \\
\hline & $\begin{array}{c}\text { Non- } \\
\text { Dust Bowl }\end{array}$ & $\begin{array}{l}\text { Dust } \\
\text { Bowl }\end{array}$ & $\begin{array}{c}\text { Rural } \\
\text { Non-DB }\end{array}$ & $\begin{array}{c}\text { Non- } \\
\text { Dust Bowl }\end{array}$ & $\begin{array}{l}\text { Dust } \\
\text { Bowl }\end{array}$ & $\begin{array}{c}\text { Rural } \\
\text { Non-DB }\end{array}$ \\
\hline constant & $\begin{array}{c}0.438 \\
(0.0388)\end{array}$ & $\begin{array}{c}0.452 \\
(0.0384)\end{array}$ & $\begin{array}{c}0.432 \\
(0.0636)\end{array}$ & $\begin{array}{c}0.429 \\
(0.0405)\end{array}$ & $\begin{array}{c}0.417 \\
(0.0416)\end{array}$ & $\begin{array}{c}0.436 \\
(0.0660)\end{array}$ \\
\hline $\begin{array}{l}a g e \\
16-25 \text { yrs }\end{array}$ & $\begin{array}{l}0.0972 \\
(0.0333)\end{array}$ & $\begin{array}{c}0.157 \\
(0.0295)\end{array}$ & $\begin{array}{l}0.0749 \\
(0.0440)\end{array}$ & $\begin{array}{l}0.0953 \\
(0.0342)\end{array}$ & $\begin{array}{c}0.171 \\
(0.0314)\end{array}$ & $\begin{array}{l}0.0706 \\
(0.0455)\end{array}$ \\
\hline $26-35$ yrs & $\begin{array}{l}0.0235 \\
(0.0152)\end{array}$ & $\begin{array}{l}0.0635 \\
(0.0218)\end{array}$ & $\begin{array}{l}0.0267 \\
(0.0216)\end{array}$ & $\begin{array}{l}0.0232 \\
(0.0155)\end{array}$ & $\begin{array}{l}0.0679 \\
(0.0229)\end{array}$ & $\begin{array}{l}0.0273 \\
(0.0218)\end{array}$ \\
\hline $36-45$ yrs & $\begin{array}{c}-0.0064 \\
(0.0123)\end{array}$ & $\begin{array}{l}0.0386 \\
(0.0194)\end{array}$ & $\begin{array}{l}0.0012 \\
(0.0171)\end{array}$ & $\begin{array}{r}-0.0064 \\
(0.0125)\end{array}$ & $\begin{array}{l}0.0483 \\
(0.0203)\end{array}$ & $\begin{array}{l}0.0005 \\
(0.0173)\end{array}$ \\
\hline family head & $\begin{array}{l}-0.163 \\
(0.0427)\end{array}$ & $\begin{array}{l}-0.146 \\
(0.0415)\end{array}$ & $\begin{array}{l}-0.152 \\
(0.0710)\end{array}$ & $\begin{array}{l}-0.146 \\
(0.0441)\end{array}$ & $\begin{array}{l}-0.130 \\
(0.0442)\end{array}$ & $\begin{array}{l}-0.142 \\
(0.0721)\end{array}$ \\
\hline married & $\begin{array}{r}-0.0622 \\
(0.0334)\end{array}$ & $\begin{array}{r}-0.0082 \\
(0.0333)\end{array}$ & $\begin{array}{r}-0.0697 \\
(0.0474)\end{array}$ & $\begin{array}{r}-0.0618 \\
(0.0341)\end{array}$ & $\begin{array}{l}0.0034 \\
(0.0349)\end{array}$ & $\begin{array}{r}-0.0721 \\
(0.0483)\end{array}$ \\
\hline young child & $\begin{array}{r}-0.0190 \\
(0.0129)\end{array}$ & $\begin{array}{l}0.0216 \\
(0.0171)\end{array}$ & $\begin{array}{r}-0.0340 \\
(0.0171)\end{array}$ & $\begin{array}{r}-0.0232 \\
(0.0131)\end{array}$ & $\begin{array}{l}0.0174 \\
(0.0179)\end{array}$ & $\begin{array}{r}-0.0371 \\
(0.0175)\end{array}$ \\
\hline in birthstate & $\begin{array}{l}-0.154 \\
(0.0124)\end{array}$ & $\begin{array}{r}-0.0998 \\
(0.0172)\end{array}$ & $\begin{array}{l}-0.132 \\
(0.0194)\end{array}$ & $\begin{array}{l}-0.154 \\
(0.0127)\end{array}$ & $\begin{array}{l}-0.112 \\
(0.0187)\end{array}$ & $\begin{array}{l}-0.135 \\
(0.0199)\end{array}$ \\
\hline home owned & $\begin{array}{c}-0.0404 \\
(0.0121)\end{array}$ & $\begin{array}{l}-0.120 \\
(0.0160)\end{array}$ & $\begin{array}{r}-0.0501 \\
(0.0176)\end{array}$ & $\begin{array}{r}-0.0398 \\
(0.0123)\end{array}$ & $\begin{array}{l}-0.103 \\
(0.0173)\end{array}$ & $\begin{array}{r}-0.0491 \\
(0.0177)\end{array}$ \\
\hline primary grad & $\begin{array}{r}-0.0100 \\
(0.0134)\end{array}$ & $\begin{array}{l}0.0488 \\
(0.0186)\end{array}$ & $\begin{array}{r}-0.0165 \\
(0.0181)\end{array}$ & $\begin{array}{r}-0.0061 \\
(0.0137)\end{array}$ & $\begin{array}{l}0.0467 \\
(0.0197)\end{array}$ & $\begin{array}{c}-0.0144 \\
(0.0184)\end{array}$ \\
\hline high school & $\begin{array}{l}0.0069 \\
(0.0158)\end{array}$ & $\begin{array}{r}-0.0242 \\
(0.0210)\end{array}$ & $\begin{array}{r}-0.0011 \\
(0.0224)\end{array}$ & $\begin{array}{l}0.0155 \\
(0.0164)\end{array}$ & $\begin{array}{r}-0.0213 \\
(0.0223)\end{array}$ & $\begin{array}{l}0.0034 \\
(0.0231)\end{array}$ \\
\hline college & $\begin{array}{l}0.0092 \\
(0.0209)\end{array}$ & $\begin{array}{r}-0.0820 \\
(0.0274)\end{array}$ & $\begin{array}{c}-0.0248 \\
(0.0334)\end{array}$ & $\begin{array}{l}0.0183 \\
(0.0214)\end{array}$ & $\begin{array}{r}-0.0687 \\
(0.0292)\end{array}$ & $\begin{array}{l}-0.0150 \\
(0.0340)\end{array}$ \\
\hline $\begin{array}{l}\text { occupation } \\
\text { farm labor }\end{array}$ & $\begin{array}{r}-0.0047 \\
(0.0400)\end{array}$ & $\begin{array}{l}0.0857 \\
(0.0331)\end{array}$ & $\begin{array}{r}-0.0016 \\
(0.0437)\end{array}$ & $\begin{array}{r}-0.0016 \\
(0.0400)\end{array}$ & $\begin{array}{l}0.0923 \\
(0.0351)\end{array}$ & $\begin{array}{r}-0.0010 \\
(0.0439)\end{array}$ \\
\hline non-farm wage & $\begin{array}{l}0.0168 \\
(0.0125)\end{array}$ & $\begin{array}{l}0.0757 \\
(0.0178)\end{array}$ & $\begin{array}{l}0.0279 \\
(0.0164)\end{array}$ & $\begin{array}{l}0.0239 \\
(0.0134)\end{array}$ & $\begin{array}{l}0.0752 \\
(0.0191)\end{array}$ & $\begin{array}{l}0.0286 \\
(0.0173)\end{array}$ \\
\hline non-farm SE & $\begin{array}{l}0.0204 \\
(0.0181)\end{array}$ & $\begin{array}{l}0.0748 \\
(0.0247)\end{array}$ & $\begin{array}{l}0.0221 \\
(0.0263)\end{array}$ & $\begin{array}{c}0.0312 \\
(0.0190)\end{array}$ & $\begin{array}{l}0.0850 \\
(0.0262)\end{array}$ & $\begin{array}{l}0.0306 \\
(0.0278)\end{array}$ \\
\hline own radio & & & & $\begin{array}{c}-0.0313 \\
(0.0121)\end{array}$ & $\begin{array}{r}-0.0804 \\
(0.0174)\end{array}$ & $\begin{array}{c}-0.0163 \\
(0.0169)\end{array}$ \\
\hline parent birthstate & & & & $\begin{array}{r}-0.0002 \\
(0.0130)\end{array}$ & $\begin{array}{l}0.0391 \\
(0.0159)\end{array}$ & $\begin{array}{c}-0.0159 \\
(0.0186)\end{array}$ \\
\hline$R^{2}$ & 0.107 & 0.074 & 0.101 & 0.107 & 0.082 & 0.100 \\
\hline observations & 4193 & 3962 & 1955 & 4060 & 3506 & 1901 \\
\hline
\end{tabular}

Notes: Coefficient estimates from the linear probability model, equation (1). See text for details on variables. Standard errors in parentheses. 
Table 15: Inter-County Migration: Fairlie Decomposition

\begin{tabular}{|c|c|c|c|c|}
\hline & \multicolumn{2}{|c|}{ Benchmark } & \multicolumn{2}{|c|}{ Extended } \\
\hline & $\begin{array}{c}\text { Dust Bowl vs } \\
\text { Non-Dust Bowl }\end{array}$ & $\begin{array}{l}\text { Dust Bowl vs } \\
\text { Rural Non-DB }\end{array}$ & $\begin{array}{l}\text { Dust Bowl vs } \\
\text { Non-DB }\end{array}$ & $\begin{array}{l}\text { Dust Bowl vs } \\
\text { Rural Non-DB }\end{array}$ \\
\hline Difference: $\bar{\pi}^{1}-\bar{\pi}^{0}$ & $\begin{array}{c}0.222 \\
(0.0110)\end{array}$ & $\begin{array}{c}0.229 \\
(0.0137)\end{array}$ & $\begin{array}{c}0.214 \\
(0.0115)\end{array}$ & $\begin{array}{c}0.221 \\
(0.0141)\end{array}$ \\
\hline Explained & $\begin{array}{c}0.0395 \\
(0.0093)\end{array}$ & $\begin{array}{c}0.0562 \\
(0.0117)\end{array}$ & $\begin{array}{c}0.0461 \\
(0.0105)\end{array}$ & $\begin{array}{c}0.0626 \\
(0.0135)\end{array}$ \\
\hline age & $\begin{array}{c}0.0035 \\
(0.0015)\end{array}$ & $\begin{array}{c}0.0026 \\
(0.0022)\end{array}$ & $\begin{array}{c}0.0027 \\
(0.0015)\end{array}$ & $\begin{array}{c}0.0016 \\
(0.0020)\end{array}$ \\
\hline schooling & $\begin{array}{l}-0.0027 \\
(0.0010)\end{array}$ & $\begin{array}{c}0.0009 \\
(0.0017)\end{array}$ & $\begin{array}{l}-0.0027 \\
(0.0010)\end{array}$ & $\begin{array}{c}0.0016 \\
(0.0017)\end{array}$ \\
\hline occupation & $\begin{array}{c}0.0005 \\
(0.0060)\end{array}$ & $\begin{array}{l}-0.0022 \\
(0.0022)\end{array}$ & $\begin{array}{l}-0.0023 \\
(0.0066)\end{array}$ & $\begin{array}{l}-0.0023 \\
(0.0028)\end{array}$ \\
\hline family structure & $\begin{array}{l}-0.0001 \\
(0.0023)\end{array}$ & $\begin{array}{c}0.0031 \\
(0.0026)\end{array}$ & $\begin{array}{l}-0.0001 \\
(0.0023)\end{array}$ & $\begin{array}{c}0.0033 \\
(0.0026)\end{array}$ \\
\hline in birthstate & $\begin{array}{c}0.0353 \\
(0.0053)\end{array}$ & $\begin{array}{c}0.0418 \\
(0.0101)\end{array}$ & $\begin{array}{c}0.0384 \\
(0.0056)\end{array}$ & $\begin{array}{c}0.0474 \\
(0.0107)\end{array}$ \\
\hline home owned & $\begin{array}{c}0.0030 \\
(0.0015)\end{array}$ & $\begin{array}{c}0.0100 \\
(0.0027)\end{array}$ & $\begin{array}{c}0.0025 \\
(0.0015)\end{array}$ & $\begin{array}{c}0.0094 \\
(0.0027)\end{array}$ \\
\hline additional & & & $\begin{array}{c}0.0077 \\
(0.0047)\end{array}$ & $\begin{array}{c}0.0016 \\
(0.0057)\end{array}$ \\
\hline Unexplained & $\begin{array}{c}0.183 \\
(0.0137)\end{array}$ & $\begin{array}{c}0.173 \\
(0.0170)\end{array}$ & $\begin{array}{c}0.168 \\
(0.0148)\end{array}$ & $\begin{array}{c}0.158 \\
(0.0184)\end{array}$ \\
\hline constant & $\begin{array}{l}-0.0264 \\
(0.0604)\end{array}$ & $\begin{array}{c}0.0198 \\
(0.0778)\end{array}$ & $\begin{array}{l}-0.0678 \\
(0.0641)\end{array}$ & $\begin{array}{l}-0.0259 \\
(0.0827)\end{array}$ \\
\hline age & $\begin{array}{l}-0.0059 \\
(0.0191)\end{array}$ & $\begin{array}{l}-0.0284 \\
(0.0242)\end{array}$ & $\begin{array}{c}0.0010 \\
(0.0196)\end{array}$ & $\begin{array}{l}-0.0199 \\
(0.0248)\end{array}$ \\
\hline schooling & $\begin{array}{l}-0.0011 \\
(0.0186)\end{array}$ & $\begin{array}{l}-0.0136 \\
(0.0230)\end{array}$ & $\begin{array}{l}-0.0070 \\
(0.0196)\end{array}$ & $\begin{array}{l}-0.0164 \\
(0.0243)\end{array}$ \\
\hline occupation & $\begin{array}{c}0.0447 \\
(0.0140)\end{array}$ & $\begin{array}{c}0.0387 \\
(0.0154)\end{array}$ & $\begin{array}{c}0.0412 \\
(0.0140)\end{array}$ & $\begin{array}{c}0.0410 \\
(0.0154)\end{array}$ \\
\hline family structure & $\begin{array}{c}0.167 \\
(0.0463)\end{array}$ & $\begin{array}{c}0.140 \\
(0.0627)\end{array}$ & $\begin{array}{c}0.189 \\
(0.0487)\end{array}$ & $\begin{array}{c}0.170 \\
(0.0654)\end{array}$ \\
\hline in birthstate & $\begin{array}{l}0.0254 \\
(0.0058)\end{array}$ & $\begin{array}{c}0.0242 \\
(0.0073)\end{array}$ & $\begin{array}{c}0.0268 \\
(0.0060)\end{array}$ & $\begin{array}{c}0.0268 \\
(0.0075)\end{array}$ \\
\hline home owned & $\begin{array}{l}-0.0205 \\
(0.0110)\end{array}$ & $\begin{array}{l}-0.0075 \\
(0.0141)\end{array}$ & $\begin{array}{l}-0.0163 \\
(0.0118)\end{array}$ & $\begin{array}{l}-0.0009 \\
(0.0148)\end{array}$ \\
\hline additional & & & $\begin{array}{c}0.0006 \\
(0.0135)\end{array}$ & $\begin{array}{l}-0.0165 \\
(0.0174)\end{array}$ \\
\hline observations & 8146 & 5913 & 7558 & 5404 \\
\hline
\end{tabular}

Notes: Estimates of Fairlie decomposition of probit specification. See text for details on variables. Standard errors in parentheses. 
Table 16: Inter-State Migration: Oaxaca-Blinder Decomposition

\begin{tabular}{|c|c|c|c|c|}
\hline & \multicolumn{2}{|c|}{ Benchmark } & \multicolumn{2}{|c|}{ Extended } \\
\hline & $\begin{array}{c}\text { Dust Bowl vs } \\
\text { Non-Dust Bowl }\end{array}$ & $\begin{array}{l}\text { Dust Bowl vs } \\
\text { Rural Non-DB }\end{array}$ & $\begin{array}{l}\text { Dust Bowl vs } \\
\text { Non-DB }\end{array}$ & $\begin{array}{l}\text { Dust Bowl vs } \\
\text { Rural Non-DB }\end{array}$ \\
\hline Difference: $\bar{\pi}^{1}-\bar{\pi}^{0}$ & $\begin{array}{c}0.193 \\
(0.0096)\end{array}$ & $\begin{array}{c}0.212 \\
(0.0112)\end{array}$ & $\begin{array}{c}0.187 \\
(0.0101)\end{array}$ & $\begin{array}{c}0.207 \\
(0.0116)\end{array}$ \\
\hline Explained & $\begin{array}{c}0.0546 \\
(0.0069)\end{array}$ & $\begin{array}{c}0.0635 \\
(0.0097)\end{array}$ & $\begin{array}{c}0.0589 \\
(0.0077)\end{array}$ & $\begin{array}{c}0.0642 \\
(0.0106)\end{array}$ \\
\hline age & $\begin{array}{c}0.0023 \\
(0.0011)\end{array}$ & $\begin{array}{c}0.0010 \\
(0.0012)\end{array}$ & $\begin{array}{c}0.0018 \\
(0.0011)\end{array}$ & $\begin{array}{c}0.0006 \\
(0.0010)\end{array}$ \\
\hline schooling & $\begin{array}{l}-0.0007 \\
(0.0007)\end{array}$ & $\begin{array}{l}-0.0008 \\
(0.0011)\end{array}$ & $\begin{array}{l}-0.0008 \\
(0.0007)\end{array}$ & $\begin{array}{l}-0.0005 \\
(0.0011)\end{array}$ \\
\hline occupation & $\begin{array}{l}-0.0059 \\
(0.0040)\end{array}$ & $\begin{array}{l}-0.0025 \\
(0.0015)\end{array}$ & $\begin{array}{l}-0.0086 \\
(0.0045)\end{array}$ & $\begin{array}{l}-0.0029 \\
(0.0019)\end{array}$ \\
\hline family structure & $\begin{array}{c}0.0011 \\
(0.0018)\end{array}$ & $\begin{array}{c}0.0032 \\
(0.0023)\end{array}$ & $\begin{array}{c}0.0007 \\
(0.0017)\end{array}$ & $\begin{array}{c}0.0030 \\
(0.0023)\end{array}$ \\
\hline in birthstate & $\begin{array}{c}0.0568 \\
(0.0049)\end{array}$ & $\begin{array}{c}0.0594 \\
(0.0089)\end{array}$ & $\begin{array}{c}0.0586 \\
(0.0051)\end{array}$ & $\begin{array}{c}0.0625 \\
(0.0094)\end{array}$ \\
\hline home owned & $\begin{array}{c}0.0009 \\
(0.0005)\end{array}$ & $\begin{array}{c}0.0032 \\
(0.0014)\end{array}$ & $\begin{array}{l}0.0007 \\
(0.0005)\end{array}$ & $\begin{array}{c}0.0030 \\
(0.0013)\end{array}$ \\
\hline additional & & & $\begin{array}{c}0.0065 \\
(0.0037)\end{array}$ & $\begin{array}{l}-0.0016 \\
(0.0043)\end{array}$ \\
\hline Unexplained & $\begin{array}{c}0.139 \\
(0.0121)\end{array}$ & $\begin{array}{c}0.148 \\
(0.0156)\end{array}$ & $\begin{array}{c}0.128 \\
(0.0130)\end{array}$ & $\begin{array}{c}0.143 \\
(0.0165)\end{array}$ \\
\hline constant & $\begin{array}{c}0.0147 \\
(0.0546)\end{array}$ & $\begin{array}{c}0.0203 \\
(0.0742)\end{array}$ & $\begin{array}{l}-0.0117 \\
(0.0581)\end{array}$ & $\begin{array}{l}-0.0184 \\
(0.0780)\end{array}$ \\
\hline age & $\begin{array}{c}0.0322 \\
(0.0158)\end{array}$ & $\begin{array}{c}0.0319 \\
(0.0184)\end{array}$ & $\begin{array}{c}0.0381 \\
(0.0162)\end{array}$ & $\begin{array}{c}0.0379 \\
(0.0187)\end{array}$ \\
\hline schooling & $\begin{array}{c}0.0053 \\
(0.0152)\end{array}$ & $\begin{array}{c}0.0130 \\
(0.0174)\end{array}$ & $\begin{array}{c}0.0015 \\
(0.0160)\end{array}$ & $\begin{array}{c}0.0110 \\
(0.0182)\end{array}$ \\
\hline occupation & $\begin{array}{c}0.0316 \\
(0.0103)\end{array}$ & $\begin{array}{c}0.0276 \\
(0.0112)\end{array}$ & $\begin{array}{c}0.0281 \\
(0.0105)\end{array}$ & $\begin{array}{c}0.0267 \\
(0.0113)\end{array}$ \\
\hline family structure & $\begin{array}{c}0.0793 \\
(0.0440)\end{array}$ & $\begin{array}{c}0.0806 \\
(0.0618)\end{array}$ & $\begin{array}{c}0.0882 \\
(0.0462)\end{array}$ & $\begin{array}{c}0.0983 \\
(0.0640)\end{array}$ \\
\hline in birthstate & $\begin{array}{l}0.0125 \\
(0.0049)\end{array}$ & $\begin{array}{c}0.0075 \\
(0.0060)\end{array}$ & $\begin{array}{c}0.0096 \\
(0.0051)\end{array}$ & $\begin{array}{c}0.0052 \\
(0.0062)\end{array}$ \\
\hline home owned & $\begin{array}{l}-0.0370 \\
(0.0094)\end{array}$ & $\begin{array}{l}-0.0325 \\
(0.0111)\end{array}$ & $\begin{array}{l}-0.0300 \\
(0.0101)\end{array}$ & $\begin{array}{l}-0.0256 \\
(0.0117)\end{array}$ \\
\hline additional & & & $\begin{array}{c}0.0044 \\
(0.0113)\end{array}$ & $\begin{array}{c}0.0075 \\
(0.0134)\end{array}$ \\
\hline observations & 8155 & 5917 & 7566 & 5407 \\
\hline
\end{tabular}

Notes: Estimates of Oaxaca-Blinder decomposition, equation (2). See text for details on variables. Standard errors in parentheses. 


\section{Additional Results: Section 4}

\section{D.1 County-Level Determinants of Migration}

Here, we include a number of county-level variables in the linear probability model for migration, equation (1). Specifically, we include measures of the average per capita level of New Deal spending during the 1930s: (i) spending on non-repayable relief grants (e.g., through the Federal Emergency Relief Administration) and public works grants (e.g., through the Works Progress Administration), and (ii) benefit payments to farmers made through the Agricultural Adjustment Administration. We also consider two measures of climactic conditions experienced in the county, all taken from Fishback et al. (2006).

Columns 1 and 4 of Table 17 present the results for the non-Dust Bowl sample. Living in a county with greater spending on relief and public works grants decreased one's probability of moving. Fishback et al. (2006) find that increased spending resulted in positive net migration into such counties, as these funds were associated with WPA employment opportunities and temporary relief for the unemployed. Qualitatively, our results are consistent with this: all else equal (in particular, holding gross in-migration equal), lower migration rates at the individual level would result in less out-migration and, hence, positive net migration.

For the non-Dust Bowl sample, increased spending on AAA benefits increased the probability of migration; this is significant at the $5 \%$ level. Fishback et al. (2006) find that AAA spending was associated with negative net migration. Since these funds were paid to farmers in exchange for culling livestock and removing land from production, this likely sped the transition of labor out of agriculture. Again, our results are consistent with this as higher individual-level migration rates in a county are associated with higher out-migration and, hence, negative net migration.

The three leftmost columns of Table 17 (Version 1) include a variable for the county's average annual precipitation during the decade, as a measure of drought and poor seasons. As column 1 indicates, the amount of precipitation has no discernible effect on an individual's probability of migration in the non-Dust Bowl sample. In our view, this is not surprising given that the normal level of precipitation varies widely with geography; as such, average annual precipitation is likely a poor measure of severe or atypical climate for the country as a whole. By contrast, our Dust Bowl sample comes from a small geographic region where normal precipitation varies little across county. As column 2 indicates, variation from the mean precipitation experienced during the 1930s is a strong predictor of mobility within the Dust Bowl: those living in counties with greater precipitation were much less likely to move. This is significant at the $5 \%$ level.

In the rightmost columns (Version 2), we replace the average annual precipitation measure with the number of months of extreme drought in the county during the 1930s. The same relationship between climate and mobility emerges for the Dust Bowl: as indicated in column 5, a greater incidence of drought is associated with higher probabilities of inter-county migration. Despite this being a better measure of climate extremes at the national level, we again find no significant relationship between weather and mobility outside of the Dust Bowl.

Finally, columns 2 and 5 indicate that within the Dust Bowl, increased relief/public works spending and AAA spending at the county level are both associated with higher migration probabilities. In all cases, this finding is statistically significant at the $1 \%$ level. ${ }^{33}$

\footnotetext{
${ }^{33}$ We note the potential endogeneity of New Deal spending with migration, making inference problematic. As such, we view the sign (as opposed to the magnitude) of the coefficient estimates as informative, and note the
} 
Table 17: Determinants of Inter-County Migration: More Regression Results

\begin{tabular}{|c|c|c|c|c|c|c|}
\hline & \multicolumn{3}{|c|}{ Version 1} & \multicolumn{3}{|c|}{ Version 2} \\
\hline & $\begin{array}{c}\text { Non- } \\
\text { Dust Bowl }\end{array}$ & $\begin{array}{l}\text { Dust } \\
\text { Bowl }\end{array}$ & $\begin{array}{c}\text { Rural } \\
\text { Non-DB }\end{array}$ & $\begin{array}{c}\text { Non- } \\
\text { Dust Bowl }\end{array}$ & $\begin{array}{l}\text { Dust } \\
\text { Bowl }\end{array}$ & $\begin{array}{c}\text { Rural } \\
\text { Non-DB }\end{array}$ \\
\hline constant & $\begin{array}{c}0.635 \\
(0.0540)\end{array}$ & $\begin{array}{c}0.631 \\
(0.0970)\end{array}$ & $\begin{array}{c}0.644 \\
(0.0807)\end{array}$ & $\begin{array}{c}0.670 \\
(0.0454)\end{array}$ & $\begin{array}{c}0.384 \\
(0.0563)\end{array}$ & $\begin{array}{c}0.629 \\
(0.0680)\end{array}$ \\
\hline $\begin{array}{l}a g e \\
16-25 \text { yrs }\end{array}$ & $\begin{array}{c}0.171 \\
(0.0406)\end{array}$ & $\begin{array}{c}0.154 \\
(0.0288)\end{array}$ & $\begin{array}{c}0.178 \\
(0.0579)\end{array}$ & $\begin{array}{c}0.172 \\
(0.0407)\end{array}$ & $\begin{array}{c}0.154 \\
(0.0288)\end{array}$ & $\begin{array}{c}0.177 \\
(0.0580)\end{array}$ \\
\hline $26-35$ yrs & $\begin{array}{l}0.0536 \\
(0.0196)\end{array}$ & $\begin{array}{l}0.0510 \\
(0.0226)\end{array}$ & $\begin{array}{l}0.0748 \\
(0.0284)\end{array}$ & $\begin{array}{l}0.0534 \\
(0.0196)\end{array}$ & $\begin{array}{l}0.0521 \\
(0.0227)\end{array}$ & $\begin{array}{l}0.0740 \\
(0.0284)\end{array}$ \\
\hline $36-45$ yrs & $\begin{array}{l}0.0222 \\
(0.0165)\end{array}$ & $\begin{array}{l}0.0296 \\
(0.0207)\end{array}$ & $\begin{array}{l}0.0518 \\
(0.0240)\end{array}$ & $\begin{array}{l}0.0219 \\
(0.0165)\end{array}$ & $\begin{array}{l}0.0311 \\
(0.0208)\end{array}$ & $\begin{array}{l}0.0522 \\
(0.0240)\end{array}$ \\
\hline family head & $\begin{array}{l}-0.215 \\
(0.0448)\end{array}$ & $\begin{array}{l}-0.127 \\
(0.0391)\end{array}$ & $\begin{array}{l}-0.205 \\
(0.0744)\end{array}$ & $\begin{array}{l}-0.216 \\
(0.0449)\end{array}$ & $\begin{array}{l}-0.129 \\
(0.0390)\end{array}$ & $\begin{array}{l}-0.206 \\
(0.0743)\end{array}$ \\
\hline married & $\begin{array}{l}-0.106 \\
(0.0372)\end{array}$ & $\begin{array}{r}-0.0080 \\
(0.0344)\end{array}$ & $\begin{array}{r}-0.0794 \\
(0.0549)\end{array}$ & $\begin{array}{l}-0.106 \\
(0.0372)\end{array}$ & $\begin{array}{r}-0.0076 \\
(0.0343)\end{array}$ & $\begin{array}{r}-0.0817 \\
(0.0549)\end{array}$ \\
\hline young child & $\begin{array}{r}-0.0496 \\
(0.0173)\end{array}$ & $\begin{array}{l}0.0210 \\
(0.0178)\end{array}$ & $\begin{array}{c}-0.0564 \\
(0.0247)\end{array}$ & $\begin{array}{c}-0.0488 \\
(0.0173)\end{array}$ & $\begin{array}{l}0.0225 \\
(0.0178)\end{array}$ & $\begin{array}{r}-0.0567 \\
(0.0247)\end{array}$ \\
\hline in birthstate & $\begin{array}{r}-0.0965 \\
(0.0152)\end{array}$ & $\begin{array}{r}-0.0160 \\
(0.0184)\end{array}$ & $\begin{array}{r}-0.0861 \\
(0.0240)\end{array}$ & $\begin{array}{r}-0.0936 \\
(0.0150)\end{array}$ & $\begin{array}{r}-0.0179 \\
(0.0184)\end{array}$ & $\begin{array}{c}-0.0874 \\
(0.0236)\end{array}$ \\
\hline $\begin{array}{l}\text { home owned } \\
\text { schooling }\end{array}$ & $\begin{array}{l}-0.125 \\
(0.0149)\end{array}$ & $\begin{array}{l}-0.212 \\
(0.0169)\end{array}$ & $\begin{array}{l}-0.147 \\
(0.0228)\end{array}$ & $\begin{array}{l}-0.124 \\
(0.0150)\end{array}$ & $\begin{array}{l}-0.213 \\
(0.0169)\end{array}$ & $\begin{array}{l}-0.146 \\
(0.0228)\end{array}$ \\
\hline primary grad & $\begin{array}{r}-0.0299 \\
(0.0178)\end{array}$ & $\begin{array}{l}0.0155 \\
(0.0194)\end{array}$ & $\begin{array}{r}-0.0218 \\
(0.0248)\end{array}$ & $\begin{array}{r}-0.0299 \\
(0.0178)\end{array}$ & $\begin{array}{l}0.0168 \\
(0.0195)\end{array}$ & $\begin{array}{r}-0.0175 \\
(0.0248)\end{array}$ \\
\hline high school & $\begin{array}{l}0.0141 \\
(0.0204)\end{array}$ & $\begin{array}{r}-0.0359 \\
(0.0218)\end{array}$ & $\begin{array}{l}0.0365 \\
(0.0304)\end{array}$ & $\begin{array}{l}0.0130 \\
(0.0203)\end{array}$ & $\begin{array}{l}-0.0358 \\
(0.0217)\end{array}$ & $\begin{array}{l}0.0387 \\
(0.0303)\end{array}$ \\
\hline college & $\begin{array}{l}0.0501 \\
(0.0254)\end{array}$ & $\begin{array}{r}-0.0390 \\
(0.0285)\end{array}$ & $\begin{array}{l}0.0585 \\
(0.0416)\end{array}$ & $\begin{array}{l}0.0490 \\
(0.0254)\end{array}$ & $\begin{array}{c}-0.0384 \\
(0.0286)\end{array}$ & $\begin{array}{l}0.0602 \\
(0.0414)\end{array}$ \\
\hline $\begin{array}{l}\text { occupation } \\
\text { farm labor }\end{array}$ & $\begin{array}{l}0.0951 \\
(0.0490)\end{array}$ & $\begin{array}{c}0.121 \\
(0.0313)\end{array}$ & $\begin{array}{c}0.0852 \\
(0.0530)\end{array}$ & $\begin{array}{l}0.0927 \\
(0.0489)\end{array}$ & $\begin{array}{c}0.122 \\
(0.0311)\end{array}$ & $\begin{array}{l}0.0851 \\
(0.0531)\end{array}$ \\
\hline non-farm wage & $\begin{array}{l}0.0210 \\
(0.0194)\end{array}$ & $\begin{array}{c}0.134 \\
(0.0184)\end{array}$ & $\begin{array}{c}0.0331 \\
(0.0246)\end{array}$ & $\begin{array}{l}0.0215 \\
(0.0194)\end{array}$ & $\begin{array}{c}0.132 \\
(0.0183)\end{array}$ & $\begin{array}{l}0.0322 \\
(0.0245)\end{array}$ \\
\hline $\begin{array}{l}\text { non-farm SE } \\
\text { county level }\end{array}$ & $\begin{array}{l}0.0041 \\
(0.0242)\end{array}$ & $\begin{array}{l}0.0538 \\
(0.0260)\end{array}$ & $\begin{array}{l}0.0017 \\
(0.0342)\end{array}$ & $\begin{array}{l}0.0037 \\
(0.0243)\end{array}$ & $\begin{array}{l}0.0534 \\
(0.0260)\end{array}$ & $\begin{array}{r}-0.0001 \\
(0.0341)\end{array}$ \\
\hline relief/public works & $\begin{array}{c}-0.0036 \\
(0.0083)\end{array}$ & $\begin{array}{l}0.0519 \\
(0.0116)\end{array}$ & $\begin{array}{r}-0.0065 \\
(0.0109)\end{array}$ & $\begin{array}{c}-0.0038 \\
(0.0083)\end{array}$ & $\begin{array}{l}0.0602 \\
(0.0118)\end{array}$ & $\begin{array}{c}-0.0033 \\
(0.0108)\end{array}$ \\
\hline AAA & $\begin{array}{l}0.0272 \\
(0.0126)\end{array}$ & $\begin{array}{l}0.0159 \\
(0.0023)\end{array}$ & $\begin{array}{l}0.0153 \\
(0.0145)\end{array}$ & $\begin{array}{l}0.0275 \\
(0.0125)\end{array}$ & $\begin{array}{l}0.0130 \\
(0.0020)\end{array}$ & $\begin{array}{l}0.0229 \\
(0.0142)\end{array}$ \\
\hline precipitation & $\begin{array}{l}0.0079 \\
(0.0084)\end{array}$ & $\begin{array}{c}-0.172 \\
(0.0703)\end{array}$ & $\begin{array}{r}-0.0067 \\
(0.0130)\end{array}$ & & & \\
\hline severe drought & & & & $\begin{array}{c}-0.0006 \\
(0.0005)\end{array}$ & $\begin{array}{l}0.0007 \\
(0.0003)\end{array}$ & $\begin{array}{r}-0.0006 \\
(0.0007)\end{array}$ \\
\hline$R^{2}$ & 0.115 & 0.124 & 0.124 & 0.115 & 0.124 & 0.125 \\
\hline observations & 4155 & 3961 & 1940 & 4155 & 3961 & 1940 \\
\hline
\end{tabular}

Notes: Coefficient estimates from the linear probability model, equation (1). See text for details on variables. Standard errors in parentheses. 


\section{D.2 Early-Decade versus Late-Decade Migrants}

To study difference between early- versus late-decade movers, we let $\pi_{i}$ in regression equation (1) take the value 1 if individual $i$ made an inter-county move between 1935 and 1940, and a value of 0 if he moved between 1930 and $1935 .{ }^{34}$ Column 1 of Table 18 presents the result of this analysis.

A number of interesting relationships emerge between the covariates and the timing of migration. The rightmost columns of Table 18 summarize the variation in covariates across early and late movers, presenting the fraction of individuals satisfying each characteristic. Being the head of a family and owning one's home are associated with moving late in the decade. For instance, of those who moved between 1930-35, only $28 \%$ were home owners; of the late-decade movers, $48 \%$ were. The coefficient estimates in column 1 indicate that being a homeowner and family head are economically and statistically significantly, even after controlling for each other and other correlated factors (such as marital status and age). Hence, there is selection on certain observables among migrants from the first and second half of the decade.

Finally, recall that farmers were the least likely occupational group to move from the Dust Bowl. Table 18 indicates that among those that moved, farmers had a greater tendency to move late in the decade. ${ }^{35}$ However, after controlling for other individual-level characteristics, this tendency is not statistically significant. This fact is made more clearly when we consider an alternative regression specification (not reported in the table) in which the three occupational dummies are replaced by a single dummy variable for farmers; in this case, the point estimate on farmer is 0.0154 with a standard error of 0.0272 .

\section{D.3 Moving to California}

The methodology we pursue is identical to that of Section 4.1. We analyze the regression model of equation (1), and restrict our attention to inter-county migrants. The outcome variable, $\pi_{i}$, now takes on a value of 1 if inter-county migrant $i$ moved to a county in California; it takes on a value of 0 if he moved to any other county (obviously, migrants who originated from California in 1930 are excluded from this analysis). The explanatory variables, $X_{i}$, are the same as those in Section 4.1, except that we include an additional age dummy for 46-55 year olds; we do so because we find statistically significant differences in migration probabilities for this age group relative to 56-60 year olds.

The regression results are presented in Table $19 .{ }^{36}$ The leftmost columns present the results for the benchmark specification. The rightmost columns present results when the dummy variable for whether the head's birth state differs from both parents is included; we found that

robustness of the results for the individual-level variables relative to Table 5. Isolating exogenous variation in spending is beyond the scope of this paper; see Fishback et al. (2006) where this issue is addressed comprehensively.

${ }^{34}$ Note that our sample is restricted, obviously, to inter-county migrants for whom the 1935 location information is discernible. Also, in this early- versus late-decade analysis, we limit attention to migrants who made only one (observable) move; those who moved both between 1930-35 and 1935-40 are excluded.

${ }^{35}$ This is consistent with the finding reported in Larson (1940) that, from estimates made by the Bureau of Agricultural Economics, the farm population in the Southern Great Plains experienced larger declines during 1935-38 than during 1930-35.

${ }^{36}$ Note that comparisons of these results with those from Section 4.1 should not be made, given the very different nature of the selected samples. In Section 4.1, the samples are representative of the resident populations, while here, the analysis conditions on those who have chosen to make an inter-county move. 
Table 18: Linear Probability Model, Early- vs. Late-Decade Migration

\begin{tabular}{|c|c|c|c|}
\hline & \multirow{2}{*}{$\begin{array}{c}\text { Regression } \\
\text { Results } \\
\end{array}$} & \multicolumn{2}{|c|}{ Summary Statistics } \\
\hline & & Early & Late \\
\hline constant & $\begin{array}{l}0.0574 \\
(0.0573)\end{array}$ & $\mathrm{n} / \mathrm{a}$ & $\mathrm{n} / \mathrm{a}$ \\
\hline age & & & \\
\hline $16-25 \mathrm{yrs}$ & $\begin{array}{l}0.0665 \\
(0.0450)\end{array}$ & 0.170 & 0.130 \\
\hline $26-35 \mathrm{yrs}$ & $\begin{array}{l}0.0632 \\
(0.0374)\end{array}$ & 0.306 & 0.313 \\
\hline $36-45 \mathrm{yrs}$ & $\begin{array}{l}0.0830 \\
(0.0357)\end{array}$ & 0.261 & 0.331 \\
\hline family head & $\begin{array}{c}0.134 \\
(0.0513)\end{array}$ & 0.855 & 0.954 \\
\hline married & $\begin{array}{l}0.0274 \\
(0.0490)\end{array}$ & 0.831 & 0.921 \\
\hline young child & $\begin{array}{l}0.0279 \\
(0.0296)\end{array}$ & 0.354 & 0.448 \\
\hline in birthstate & $\begin{array}{l}0.0494 \\
(0.0296)\end{array}$ & 0.238 & 0.287 \\
\hline home owned & $\begin{array}{c}0.154 \\
(0.0288)\end{array}$ & 0.299 & 0.487 \\
\hline $\begin{array}{l}\text { schooling } \\
\text { primary grad }\end{array}$ & $\begin{array}{l}0.0172 \\
(0.0312)\end{array}$ & 0.375 & 0.402 \\
\hline high school & $\begin{array}{c}-0.0404 \\
(0.0354)\end{array}$ & 0.266 & 0.230 \\
\hline college & $\begin{array}{l}0.0731 \\
(0.0543)\end{array}$ & 0.072 & 0.092 \\
\hline $\begin{array}{l}\text { occupation } \\
\text { farm labor }\end{array}$ & $\begin{array}{r}-0.0361 \\
(0.0460)\end{array}$ & 0.109 & 0.063 \\
\hline non-farm wage & $\begin{array}{c}-0.0018 \\
(0.0297)\end{array}$ & 0.377 & 0.349 \\
\hline non-farm SE & $\begin{array}{c}-0.0390 \\
(0.0454)\end{array}$ & 0.095 & 0.095 \\
\hline own radio & $\begin{array}{l}0.0441 \\
(0.0316)\end{array}$ & 0.196 & 0.271 \\
\hline $\begin{array}{l}R^{2} \\
\text { observations }\end{array}$ & $\begin{array}{c}0.056 \\
1420\end{array}$ & & \\
\hline
\end{tabular}

Notes: See text for details on variables. Standard errors in parentheses.

${ }^{*}: p<0.10,{ }^{* *}: p<0.05,{ }^{* * *}: p<0.01$ 
Table 19: Linear Probability Model, Moving to California: Regression Results

\begin{tabular}{|c|c|c|c|c|c|c|}
\hline & \multicolumn{3}{|c|}{ Benchmark } & \multicolumn{3}{|c|}{ Extended } \\
\hline & $\begin{array}{c}\text { Non- } \\
\text { Dust Bowl }\end{array}$ & $\begin{array}{l}\text { Dust } \\
\text { Bowl }\end{array}$ & $\begin{array}{c}\text { Rural } \\
\text { Non-DB }\end{array}$ & $\begin{array}{c}\text { Non- } \\
\text { Dust Bowl }\end{array}$ & $\begin{array}{l}\text { Dust } \\
\text { Bowl }\end{array}$ & $\begin{array}{c}\text { Rural } \\
\text { Non-DB }\end{array}$ \\
\hline constant & $\begin{array}{l}0.0391 \\
(0.0437)\end{array}$ & $\begin{array}{c}0.121 \\
(0.0453)\end{array}$ & $\begin{array}{c}0.115 \\
(0.0795)\end{array}$ & $\begin{array}{l}0.0081 \\
(0.0515)\end{array}$ & $\begin{array}{c}0.124 \\
(0.0547)\end{array}$ & $\begin{array}{l}0.0548 \\
(0.0701)\end{array}$ \\
\hline $\begin{array}{l}\text { age } \\
16-25 \text { yrs }\end{array}$ & $\begin{array}{c}0.100 \\
(0.0417)\end{array}$ & $\begin{array}{r}-0.0512 \\
(0.0410)\end{array}$ & $\begin{array}{l}0.0930 \\
(0.0572)\end{array}$ & $\begin{array}{l}0.0921 \\
(0.0412)\end{array}$ & $\begin{array}{r}-0.0687 \\
(0.0457)\end{array}$ & $\begin{array}{l}0.0808 \\
(0.0558)\end{array}$ \\
\hline $26-35$ yrs & $\begin{array}{l}0.0576 \\
(0.0297)\end{array}$ & $\begin{array}{r}-0.0589 \\
(0.0392)\end{array}$ & $\begin{array}{l}0.0438 \\
(0.0447)\end{array}$ & $\begin{array}{l}0.0589 \\
(0.0293)\end{array}$ & $\begin{array}{r}-0.0799 \\
(0.0437)\end{array}$ & $\begin{array}{l}0.0432 \\
(0.0455)\end{array}$ \\
\hline $36-45$ yrs & $\begin{array}{l}0.0352 \\
(0.0271)\end{array}$ & $\begin{array}{r}-0.0778 \\
(0.0389)\end{array}$ & $\begin{array}{l}0.0497 \\
(0.0427)\end{array}$ & $\begin{array}{l}0.0378 \\
(0.0269)\end{array}$ & $\begin{array}{r}-0.0978 \\
(0.0434)\end{array}$ & $\begin{array}{l}0.0455 \\
(0.0439)\end{array}$ \\
\hline $46-55$ yrs & $\begin{array}{l}0.0493 \\
(0.0289)\end{array}$ & $\begin{array}{r}-0.0535 \\
(0.0402)\end{array}$ & $\begin{array}{l}0.0638 \\
(0.0459)\end{array}$ & $\begin{array}{l}0.0456 \\
(0.0283)\end{array}$ & $\begin{array}{r}-0.0601 \\
(0.0450)\end{array}$ & $\begin{array}{l}0.0486 \\
(0.0464)\end{array}$ \\
\hline family head & $\begin{array}{l}0.0379 \\
(0.0598)\end{array}$ & $\begin{array}{l}0.0151 \\
(0.0300)\end{array}$ & $\begin{array}{c}-0.0064 \\
(0.0952)\end{array}$ & $\begin{array}{l}0.0363 \\
(0.0628)\end{array}$ & $\begin{array}{l}0.0147 \\
(0.0336)\end{array}$ & $\begin{array}{l}0.0201 \\
(0.0937)\end{array}$ \\
\hline married & $\begin{array}{l}-0.0660 \\
(0.0584)\end{array}$ & $\begin{array}{r}-0.0096 \\
(0.0292)\end{array}$ & $\begin{array}{l}-0.119 \\
(0.0820)\end{array}$ & $\begin{array}{r}-0.0515 \\
(0.0600)\end{array}$ & $\begin{array}{r}-0.0078 \\
(0.0322)\end{array}$ & $\begin{array}{l}-0.107 \\
(0.0822)\end{array}$ \\
\hline young child & $\begin{array}{c}-0.0054 \\
(0.0191)\end{array}$ & $\begin{array}{l}0.0138 \\
(0.0156)\end{array}$ & $\begin{array}{r}-0.0202 \\
(0.0219)\end{array}$ & $\begin{array}{r}-0.0093 \\
(0.0193)\end{array}$ & $\begin{array}{l}0.0141 \\
(0.0166)\end{array}$ & $\begin{array}{l}-0.0178 \\
(0.0222)\end{array}$ \\
\hline in birthstate & $\begin{array}{r}-0.0447 \\
(0.0190)\end{array}$ & $\begin{array}{l}0.0147 \\
(0.0161)\end{array}$ & $\begin{array}{r}-0.0145 \\
(0.0286)\end{array}$ & $\begin{array}{l}-0.0440 \\
(0.0188)\end{array}$ & $\begin{array}{l}0.0036 \\
(0.0169)\end{array}$ & $\begin{array}{l}-0.0127 \\
(0.0284)\end{array}$ \\
\hline $\begin{array}{l}\text { home owned } \\
\text { schooling }\end{array}$ & $\begin{array}{l}0.0210 \\
(0.0216)\end{array}$ & $\begin{array}{l}0.0311 \\
(0.0159)\end{array}$ & $\begin{array}{l}0.0227 \\
(0.0341)\end{array}$ & $\begin{array}{l}0.0280 \\
(0.0219)\end{array}$ & $\begin{array}{l}0.0367 \\
(0.0171)\end{array}$ & $\begin{array}{l}0.0377 \\
(0.0344)\end{array}$ \\
\hline primary grad & $\begin{array}{l}0.0148 \\
(0.0225)\end{array}$ & $\begin{array}{r}-0.0013 \\
(0.0171)\end{array}$ & $\begin{array}{l}0.0179 \\
(0.0313)\end{array}$ & $\begin{array}{l}0.0181 \\
(0.0211)\end{array}$ & $\begin{array}{r}-0.0008 \\
(0.0184)\end{array}$ & $\begin{array}{l}0.0335 \\
(0.0282)\end{array}$ \\
\hline high school & $\begin{array}{l}-0.0005 \\
(0.0259)\end{array}$ & $\begin{array}{l}0.0106 \\
(0.0202)\end{array}$ & $\begin{array}{l}-0.0016 \\
(0.0373)\end{array}$ & $\begin{array}{l}0.0062 \\
(0.0238)\end{array}$ & $\begin{array}{l}0.0094 \\
(0.0215)\end{array}$ & $\begin{array}{l}0.0208 \\
(0.0322)\end{array}$ \\
\hline college & $\begin{array}{l}0.0027 \\
(0.0325)\end{array}$ & $\begin{array}{c}-0.0435 \\
(0.0236)\end{array}$ & $\begin{array}{l}0.0040 \\
(0.0654)\end{array}$ & $\begin{array}{l}0.0086 \\
(0.0312)\end{array}$ & $\begin{array}{r}-0.0469 \\
(0.0244)\end{array}$ & $\begin{array}{l}0.0420 \\
(0.0587)\end{array}$ \\
\hline $\begin{array}{l}\text { occupation } \\
\text { farm labor }\end{array}$ & $\begin{array}{r}-0.0456 \\
(0.0407)\end{array}$ & $\begin{array}{l}0.0403 \\
(0.0270)\end{array}$ & $\begin{array}{r}-0.0619 \\
(0.0481)\end{array}$ & $\begin{array}{l}-0.0381 \\
(0.0407)\end{array}$ & $\begin{array}{l}0.0587 \\
(0.0293)\end{array}$ & $\begin{array}{r}-0.0436 \\
(0.0456)\end{array}$ \\
\hline non-farm wage & $\begin{array}{l}0.0272 \\
(0.0224)\end{array}$ & $\begin{array}{l}0.0133 \\
(0.0157)\end{array}$ & $\begin{array}{l}0.0373 \\
(0.0280)\end{array}$ & $\begin{array}{c}0.0226 \\
(0.0223)\end{array}$ & $\begin{array}{l}0.0225 \\
(0.0168)\end{array}$ & $\begin{array}{c}0.0300 \\
(0.0277)\end{array}$ \\
\hline non-farm SE & $\begin{array}{l}0.0207 \\
(0.0322)\end{array}$ & $\begin{array}{l}0.0597 \\
(0.0283)\end{array}$ & $\begin{array}{c}-0.0338 \\
(0.0370)\end{array}$ & $\begin{array}{l}0.0130 \\
(0.0327)\end{array}$ & $\begin{array}{l}0.0737 \\
(0.0312)\end{array}$ & $\begin{array}{r}-0.0587 \\
(0.0331)\end{array}$ \\
\hline parent birthstate & & & & $\begin{array}{c}0.0726 \\
(0.0249)\end{array}$ & $\begin{array}{l}0.0139 \\
(0.0147)\end{array}$ & $\begin{array}{l}0.0427 \\
(0.0355)\end{array}$ \\
\hline$R^{2}$ & 0.028 & 0.012 & 0.073 & 0.039 & 0.018 & 0.069 \\
\hline observations & 1054 & 2050 & 480 & 1018 & 1783 & 465 \\
\hline
\end{tabular}

Notes: See text for details on variables. Standard errors in parentheses. ${ }^{*}: p<0.10,{ }^{* *}: p<0.05,{ }^{* * *}: p<0.01$ 
owning a radio had no explanatory power, so that variable has been omitted here. A number of interesting differences are apparent between Dust Bowl migrants and those from elsewhere.

The most obvious is the very different age profile of movers to California. For migrants outside the Dust Bowl, the excluded age group of 55-60 year olds was least likely to move to California; the most likely was the youngest, aged 16-25. By contrast, among Dust Bowl migrants, it is the oldest group of 55-60 year olds that was most likely to move there; while only the estimated age dummy for 36-45 year olds is statistically significant, all four age dummies are negative and economically significant.

Second, conditional on moving counties, residing in one's birth state in 1930 has strong negative predictive power outside the Dust Bowl with respect to California migration. The results for the extended specification indicate that this is also true for those born outside of their parents' birth state. Hence, for non-Dust Bowl migrants, those with a history of personal mobility or "inherited family mobility" are more likely to move to California. By contrast, neither of these results bear out among the Dust Bowl migrants.

Within the Dust Bowl sample, of the four occupational groups, it is the non-farm selfemployed who were most likely to move to California. It is interesting to note that this contrasts with the popular notion that those who went west were displaced farmers and farm laborers seeking agricultural work in California's produce fields and orchards. The fact that the selfemployed and home owners (as opposed to renters) were more likely to move to California suggests that a degree of personal wealth was relevant for such a move. By contrast, no clear or statistically significant relationship exists between occupation or home-ownership and California migration outside of the Dust Bowl.

Finally, we have conducted this regression analysis for the 1920s sample of migrants from the Dust Bowl region. For brevity, we do not display the results here and make them available upon request. We briefly note two findings. First, the age profile of movers to California in the 1920s is decreasing, as is the case in the non-Dust Bowl samples of the 1930s. That the 55-60 year olds were most likely to move to California is unique to the Dust Bowl migrants. And finally, as with the non-Dust Bowlers of the 1930s, residing in one's birth state in 1920 is a strong negative predictor of California migration in the 1920s sample. Hence, the fact that living in one's birth state is unrelated to moving to California in the 1930s is, again, unique to the Dust Bowl. 


\section{References}

Abramitzky, R., L. P. Boustan, and K. Eriksson (2012). Europe's tired, poor, huddled masses: Self-selection and economic outcomes in the age of mass migration. American Economic Review 102(5), 1832-1856.

Barton, G. T. and J. McNeely (1939). Recent changes in farm labor organization in three Arkansas plantation counties. Preliminary report, University of Arkansas, Agricultural Experiment Station.

Blinder, A. (1973). Wage discrimination: Reduced form and structural estimates. Journal of Human Resources 8, 436-455.

Collins, W. and M. Wanamaker (2014). Selection and economic gains in the great migration of african americans: New evidence with linked census data. American Economic Journal: Applied Economics 6(1), 220-252.

Cunfer, G. (2005). On the Great Plains: Agriculture and Environment. College Station: Texas A\&M University Press.

Cunfer, G. (2011). The southern great plains wind erosion maps of 1936-1937. Agricultural History 85(4), 540-559.

Fairlie, R. W. (1999). The absence of the african-american owned business: An analysis of the dynamics of self-employment. Journal of Labor Economics 17, 80-108.

Ferrie, J. P. (2003). Internal migration. In S. B. Carter, S. S. Gartner, M. R. Haines, A. L. Olmstead, R. Sutch, and G. Wright (Eds.), Historical Statistics of the United States, Earliest Times to the Present: Millennial Edition, Volume 1, pp. 489-94. Cambridge University Press.

Fishback, P. V., W. C. Horrace, and S. Kantor (2006). The impact of New Deal expenditures on mobility during the Great Depression. Explorations in Economic History 43(2), 179-222.

Hansen, Z. K. and G. D. Libecap (2004). Small farms, externalities, and the dust bowl of the 1930s. Journal of Political Economy 112(3), 665-694.

Hoffman, C. S. (1938). Drought and depression migration into Oregon, 1930 to 1936. Monthly Labor Review 46(1), 27-35.

Hornbeck, R. (2012). The enduring impact of the American Dust Bowl: Short- and long-run adjustments to environmental catastrophe. American Economic Review 102(4), 1477-1507.

Janow, S. J. (1940). Volume and characteristics of recent migration to the far west. In Hearings Before the Select Committee to Investigate the Interstate Migration of Destitute Citizens, 76th Congress, 3rd Session, pp. 2269-2326. 
Joel, A. H. (1937). Soil conservation reconnaissance survey of the southern great plains winderosion area. Technical Bulletin 556, U.S. Department of Agriculture, Washington, D.C.: Government Printing Office.

Kraenzel, C. F. (1939). Farm population mobility in selected Montana communities. Bulletin 371, Montana State College, Agricultural Experiment Station.

Lane, N. (1938). The dust farmer goes west. Land Policy Review 1(1), 21-25.

Larson, O. F. (1940). Farm population mobility in the Southern Great Plains. Social Forces 18(4), 514-520.

Long, J. (2005). Rural-urban migration and socioeconomic mobility in Victorian Britain. The Journal of Economic History 65(1), 1-35.

Long, J. and J. Ferrie (2013). Intergenerational occupational mobility in Great Britain and the United States since 1850. American Economic Review 103(4), 1109-1137.

Maddala, G. (1983). Limited-Dependent and Qualitative Variables in Econometrics. Cambridge: Cambridge University Press.

Malin, J. C. (1935). The turnover of farm population in Kansas. Kansas Historical Quarterly $4(4), 339-372$.

Malin, J. C. (1961). The Grassland of North America: Prolegomena to Its History. Lawrence, Kansas: self published.

McKenzie, D., J. Gibson, and S. Stillman (2010). How important is selection? experimental vs. non-experimental measures of the income gains from migration. Journal of the European Economic Association 8(4), 913-945.

McMillan, R. T. (1936). Some observations on Oklahoma population movements since 1930. Rural Sociology 1(3), 332-343.

Molloy, R., C. L. Smith, and A. Wozniak (2011). Internal migration in the United States. Journal of Economic Perspectives 25(2), 1-42.

Oaxaca, R. (1973). Male-female wage differentials in urban labor markets. International Economic Review 14, 693-709.

Rosenbloom, J. L. and W. A. Sundstrom (2004). The decline and rise of interstate migration in the United States: Evidence from the IPUMS, 1850-1990. In A. Field (Ed.), Research in Economic History, Volume 22, pp. 289-325. Elsevier. 
Rowell, E. J. (1936). Drought refugee and labor migration to California in 1936. Monthly Labor Review 43(6), 1355-1363.

Ruggles, S., J. T. Alexander, K. Genadek, R. Goeken, M. B. Schroeder, and M. Sobek (2010). Integrated Public Use Microdata Series: Version 5.0 [machine-readable database].

Taeuber, C. and C. S. Hoffman (1937). Recent migration from the drought areas. U.S. Farm Security Administration Land Policy Circular (September), 16-20.

Taylor, P. S. and T. Vasey (1936). Drought refugee and labor migration to California, JuneDecember 1935. Monthly Labor Review 42(2), 312-318.

U.S. Bureau of Agricultural Economics (1939). Agricultural Outlook Charts, 1940. Washington, D.C.

U.S. Bureau of the Census (1946). Sixteenth Census of the United States: 1940. Population, Internal Migration, 1935 to 1940. Washington, D.C.: Government Printing Office.

U.S. House (1941). Interstate Migration. Report of the Select Committee to investigate the interstate migration of destitute citizens. Washington, D.C.: Government Printing Office.

Webb, J. N. and M. Brown (1938). Migrant Families. Works Progress Administration, Research Monograph XVIII. Washington, D.C.: Government Printing Office.

Worster, D. (1979). Dust Bowl: The Southern Plains in the 1930s. New York: Oxford University Press.

Ziebarth, N. L. (2013). The radio and bank distress in the great depression. Manuscript, University of Iowa. 